\title{
Compartimentação geomorfológica da foz do Rio Jaguaribe e áreas costeiras adjacentes (Ceará, Nordeste do Brasil)
}

\author{
Geomorphological compartmentalization of the Jaguaribe River mouth and adjacent \\ coastal areas (Ceará, Northeast Brazil)
}

\author{
CARVALHO NETA ${ }^{1}$, M. L.; CLAUDINO SALES ${ }^{2}$, V.
}

carvalhoneta@gmail.com

\begin{abstract}
Resumo
O presente trabalho apresenta uma análise dos elementos geoambientais e das feições geomorfológicas da desembocadura do Rio Jaguaribe e áreas costeiras adjacentes. Trata-se do recurso hídrico de maior abrangência e importância no Estado do Ceará, com foz caracterizada pela ocorrência de uma série de atividades socioeconômicas que via de regra estão alterando de forma negativa o meio ambiente. A pesquisa foi realizada a partir do uso da análise ambiental, pautada na metodologia geossistêmica, e contou com etapas de gabinete, laboratório (geoprocessamento) e trabalhos de campo, a partir do que foram consideradas a planície fluvial, a faixa de praia, os campos de dunas móveis e de dunas fixas, a planície flúvio-marinha e os tabuleiros costeiros. A perspectiva do artigo é contribuir para a ampliação do conhecimento acerca do substrato natural da zona costeira cearense, com foque especial para a área de estudo, visando subsidiar o planejamento ambiental e formas mais sustentáveis de uso e ocupação do espaço regional. .
\end{abstract}

Palavras-chave: geomorfologia, geoambiente, foz do Rio Jaguaribe, análise ambiental.

\begin{abstract}
The present work presents an analysis of the geoenvironmental elements and the geomorphological features of the mouth of the Jaguaribe River and adjacent coastal areas. It is the resource of water resources of greater importance in the State of Ceará, with a mouth characterized by the occurrence of a series of socioeconomic activities that as a rule are changing the environment in a negative way. The research was carried out from the use of environmental analysis, based on the geosystemic methodology, and counted on steps of cabinet, laboratory (geoprocessing) and fieldwork, from what were considered the fluvial plain, the strip of beach, the fields of mobile dunes and fixed dunes, the fluvial-marine plain and the coastal table feature. The aim of the article is to contribute to the expansion of knowledge about the natural substrate of the coastal zone of Ceará, with special focus on the study area, aiming to subsidize environmental planning and more sustainable forms of use and occupation of the regional space. .
\end{abstract}

Key words: geomorphology, geoenvironment, Jaguaribe River mouth, environmental analysis.

\section{INTRODUÇÃO}

Uma bacia hidrográfica apresenta características geoambientais específicas, formando uma unidade natural indissociável. É um sistema complexo, dado o número de elementos e variáveis envolvidas. A relação mútua existente entre componentes estruturais em uma bacia hidrográfica possibilita a análise integrada do seu meio ambiente, permitindo uma apurada

\footnotetext{
${ }^{1}$ Maria de Lourdes Carvalho Neta, Departamento de Geociências,Universidade Regional do Cariri, Crato-CE, Brasil.

${ }^{2}$ Vanda Claudino Sales, Universidade Estadual Vale do Acaraú, Fortaleza-CE, Brasil.
} 
avaliação dos aspectos físicos, econômicos e sociais (NASCIMENTO, 2003).

No Estado do Ceará, localizado na região Nordeste do Brasil, ocorrem diversas bacias hidrográficas, divididas em doze regiões hidrográficas, definidas pelo Plano Estadual de Recursos Hídricos de 1992 como unidades de planejamento, a saber: Metropolitana, Acaraú, Alto Jaguaribe, Baixo Jaguaribe, Banabuiú, Coreaú, Curu, Litoral, Médio Jaguaribe, Salgado, Serra da Ibiapaba e Sertões de Crateús (COGERH, 2018).

A bacia hidrográfica do Rio Jaguaribe, o maior do Estado, é representado por cinco dessas regiões (Banabuíu, Baixo Jaguaribe, Médio Jaguaribe, Alto Jaguaribe e Salgado). A bacia ocupa aproximadamente $48 \%$ do território estadual, apresentando cerca de $74.000 \mathrm{~km}^{2}$ de área e uma extensão de 610 km, desde a Serra da Joaninha, no município de Tauá, onde se encontram as nascentes (sudoeste do Estado), até o município de Fortim (a norte), onde deságua no oceano Atlântico (COGERH, 2018). Situada no setor leste do litoral do Estado do Ceará, mais precisamente a sudeste de Fortaleza, a área de pesquisa, integrante da região hidrográfica definida como Baixo Jaguaribe, corresponde à desembocadura desse rio (Figura $1)$.

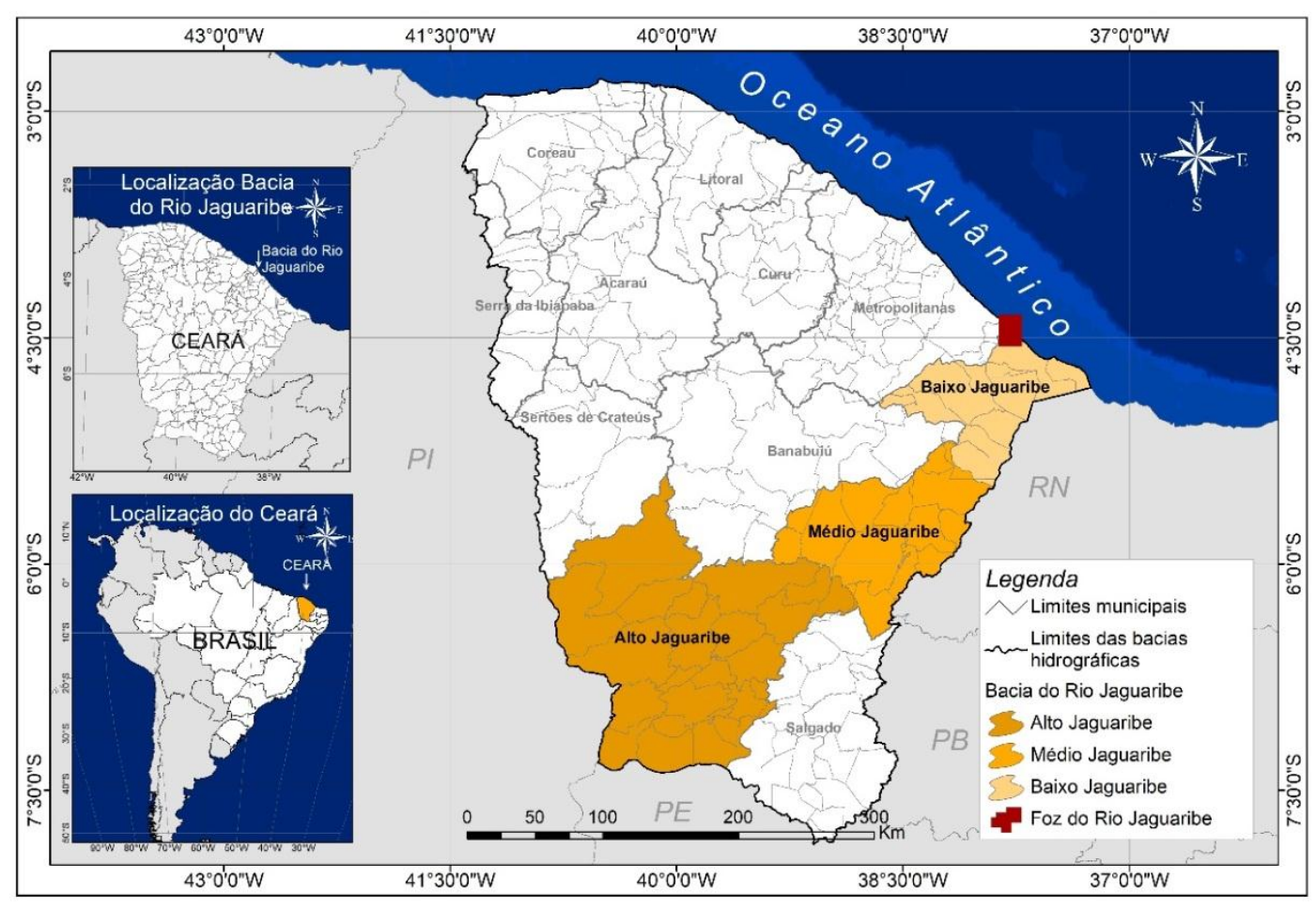

Figura 1: Localização da bacia do Rio Jaguaribe, com indicação da foz do rio. 
Com efeito, o objetivo geral do presente trabalho é apresentar a compartimentação geomorfológica da desembocadura do Rio Jaguaribe e áreas adjacentes (Figura 2), através da caracterização geoambiental e do mapeamento das principais tipos de relevos presentes da área, na perspectiva de contribuir para a ampliação do conhecimento acerca do substrato natural da zona costeira cearense. Tal fato se coloca como fundamental para pautar de forma racional as atividades sociais que aí se desenvolvem, bem como para subsidiar o planejamento ambiental e as atividades administrativas no município de Aracati, no qual a região em questão de insere.

\section{MÉTODOS E TÉCNICAS}

O suporte teórico-metodológico adotado nesse trabalho foi a "análise ambiental", que tem suas raizes na "análise geossistêmica" de Sotchava (1977).

O critério fundamental da análise geossistêmica é o de considerar as relações mútuas entre os componentes de um sistema visando analisar o estado de inter-relações e interdependências entre o sistema natural e entre o sistema natural e humano, procurando definir a sensibilidade e a resistência do ambiente.

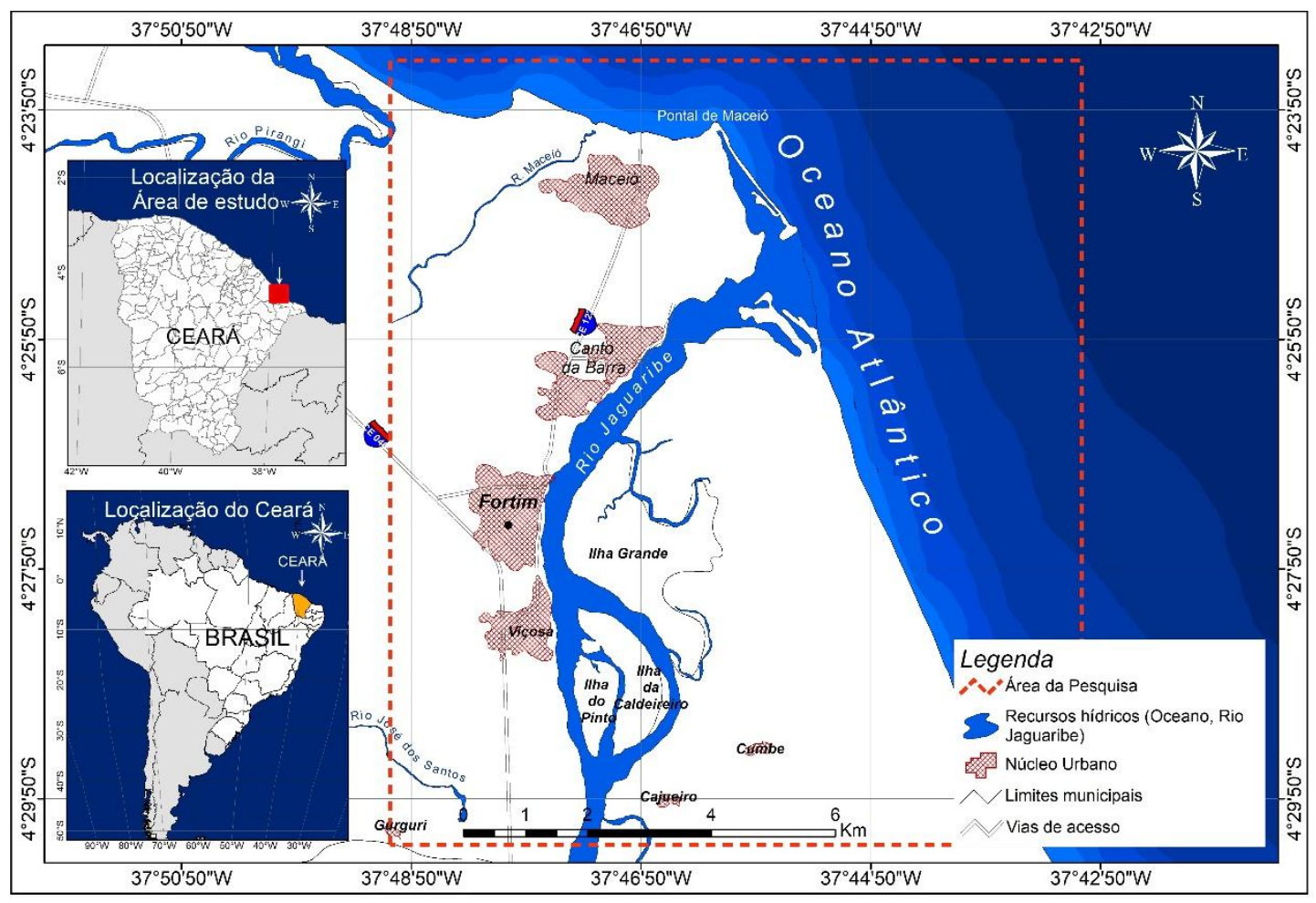

Figura 2: Localização da área de pesquisa - foz do Rio Jaguaribe e setores costeiros adjacentes. 
A análise geossistêmica propicia o conhecimento de cada elemento que compõe o meio natural, ao mesmo tempo em que possibilita a interpretação das inter-relações entre as partes do todo (BERTRAND, 1969). Bertrand (1969), Sotchava (1977), Tricart (1977), Christofoletti (1979), Troppmair (1989), Rodriguez et al (2004), entre outros autores, desenvolveram estudos integrados da paisagem, tendo como fundamentação teóricometodológica a TGS direcionada para estudos geossistêmicos e geoambientais.

A análise ambiental, por sua vez, e como indicado por Mendonça (1999), considera as diferentes variáveis do meio natural, numa visão sistêmica, associando-as com os aspectos sociais e econômicos, em uma abordagem integrada. Nesse trabalho, foram definidas unidades de relevo e suas dinâmicas naturais, o que se deu através da compartimentação geomorfológica da área de estudo. Foram também analisados os problemas ambientais que caracterizam a área de pesquisa na atualidade, resultantes de diversos tipos de usos e ocupações do ambiente natural. Tal procedimento caracteriza o trabalho, do ponto de vista metodológico, como resultante de análise ambiental integrada, tendo como objeto a foz do Rio Jaguaribe e áreas adjacentes.

Do ponto de vista das técnicas, foram realizadas atividades de gabinete, laboratório e campo. As atividades de gabinete foram associadas ao levantamento bibliográfico e cartográfico detalhado da área de estudo, implicando em visitas à orgãos públicos e bibliotecas, para coleta e posterior análise do material pré-existente.

A etapa de laboratório implicou na manipulação das bases cartográficas para produção das informações espaciais da pesquisa. O processamento digital das imagens e posterior produção de informações espaciais concretizaram-se embasados na técnica de sensoriamento remoto. Essa técnica permite obter informações da superfície da terra à distância, ou seja, obtém informações sobre objetos através de dados coletados por instrumentos que não estejam em contato físico com os objetos investigados (FUCKS et al, 2004). Nessa perspectiva, foi realizada a delimitação dos elementos geoambientais da foz do Rio Jaguaribe, através da ferramenta r.watershed/GrassGIS do software Qgis 2.18.11, tendo por entrada o Modelo Digital de Elevação SRTM (Shuttle Radar Topography Mission) distribuído pelo USGS (United States Geological Survey) para a área de estudos. O desenvolvimento dos mapas de Geologia e Geomorfologia tiveram por base cartográfica dados do IBGE (Instituto Brasileiro de Geografia e Estatística), que foram confrontados aos referidos dados de elevação para a delimitação das respectivas unidades geológicas e geomorfológicas, por meio de processos de digitalização vetorial. A organização e apresentação dos mapas foi implementada com o compositor de impressões do Qgis 2.18.11.

Posteriormente à etapa de laboratório, iniciaram-se os trabalhos de campo. Realizaram-se 
observações e anotações acerca das unidades de paisagem identificadas, além de registros fotográficos, com uso de GPS. Dentre as atividades desenvolvidas na etapa de campo destacam-se navegação com barco através no baixo curso do Rio Jaguaribe e percurso efetuado com bugre sobre o campo de dunas móveis e faixa de praias, objetivando o reconhecimento fisiográfico da área e o levantamento de dados relativos a problemas ambientais.

Os resultados desses procedimentos metodológicos e técnicos acham-se expressos nos itens a seguir.

\section{CONDICIONANTES GEOAMBIENTAIS DA AREA DE ESTUDO}

$\mathrm{Na}$ área de pesquisa, a geologia está representada, basicamente, pelos sedimentos da Formação Barreiras, por manchas isoladas da Formação Tibau, e pelas areias dos aluviões, faixas de praia e campos de dunas (CPRM, 2014, 2003) (Figura 3).

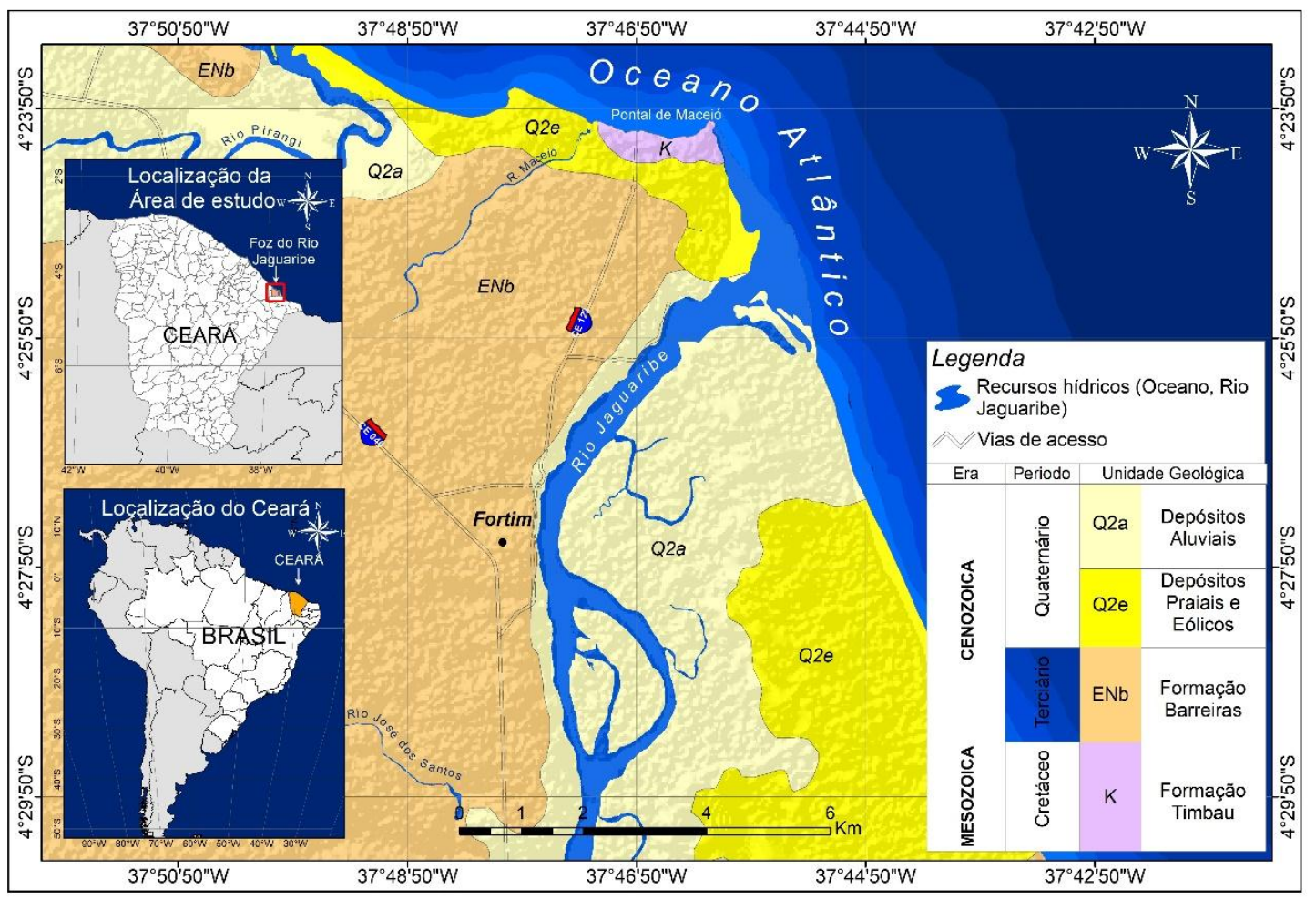

Figura 3: Esboço geológico foz do rio Jaguaribe/CE. Fonte: Adaptado de CPRM, 2003 e 2014.

Cronologicamente, as unidades lito-estratigráficas presentes na área, encontram-se posicionadas desde o Cretáceo (Formação Timbau), Oligoceno-Plioceno (período Terciário: Formação Barreiras) até o Holoceno (período Quaternário: os depósitos eólicos e litorâneos, e 
os depósitos aluvionares) (CPRM, 2014).

Tratando da litologia, a Formação Barreiras é constituída por sedimentos arenoargilosos, pouco litificados, de coloração avermelhada, creme ou amarelada. Sua granulação varia entre fina e média, contendo intercalações de níveis conglomératicos. (CPRM, 2014).

A Formação Tibau repousa diretamente sobre a Formação Jandaíra na Bacia Potiguar (situada a leste da área de pesquisa), aflorando como paredão fluvial na margem esquerda do baixo curso do Jaguaribe próximo a cidade de Fortim, e, ainda, na localidade de Maceió, na forma de falésias ativas. Essa formação constitui o suporte geológico do promontório denominado "Pontal do Maceió", situada na margem esquerda da foz. Litologicamente compreende arenitos médios a conglomératicos, com tons variando do verde amarelado a creme, mal selecionados, duros e friáveis, contendo quartzo e feldspato (CASTELO BRANCO, 1996).

Os depósitos da planície litorânea representam unidade constituída por sedimentos inconsolidados que formam as faixas de praias, barreiras e acumulações dunares que se distribuem continuamente e de forma paralela à linha de costa. Os sedimentos desta unidade são representados por areias esbranquiçadas, de granulação grossa, média e fina, composta por grãos de quartzo (PEDROSA, 2016; CLAUDINO-SALES, 2005).

Os depósitos aluviais são formados por sedimentos de origem fluvial de períodos recentes, localmente influenciados pela ação marinha, sendo representados principalmente por argilas, areias e cascalhos (CPRM, 2014).

O clima regional é semi-árido, apresentando irregularidades pluviométricas temporoespacial. O regime pluviométrico da região é do tipo tropical com estação de chuvas concentradas em cinco meses consecutivos. No litoral ocorrem chuvas mais abundantes que ultrapassam anualmente 900 a 1000 mm. Para o interior, há um decréscimo sensível das chuvas e os valores ficam abaixo de $700 \mathrm{~mm}$ anuais (SOUZA, 2002; ZANELA, 2007).

A concentração das chuvas no Estado do Ceará sofre a influência direta da Zona de Convergência Intertropical - ZCIT, principal sistema atmosférico causador da precipitação. A ZCIT se forma na confluência dos ventos alísios de NE e SE, onde ocorre a ascendência do ar, formação de nebulosidade e muita chuva. Tal zona se localiza próxima à linha do Equador e, no transcorrer do ano, migra para os hemisférios Norte e Sul, atingindo sua posição mais meridional no verão/outono, quando ocorrem as maiores chuvas no Estado, período chamado popularmente de inverno (ZANELA, 2005).

O regime térmico da região é caracterizado, basicamente, por temperaturas elevadas e amplitudes térmicas reduzidas. A temperatura média anual é de $26{ }^{\circ} \mathrm{C}$, com variações não 
ultrapassando $5{ }^{\circ} \mathrm{C}$ (MAIA, 1998). A pouca variação das temperaturas deve-se ao caráter tropical da região e a sua proximidade da linha do Equador.

O regime eólico no litoral do estado é controlado basicamente pelos alísios, os quais atingem a costa, provindos do quadrante E. No primeiro semestre do ano, predominam os alísios de NE, no segundo semestre, há um domínio dos alísios de SE, eles sopram a velocidades que podem variar entre $4 \mathrm{~m} / \mathrm{s}$ (alísios de NE sobretudo) e $7 \mathrm{~m} / \mathrm{s}$, respectivamente (MAIA, 1998; FUNCEME, 2018). Os alísios de SE, mais intensos que os de NE, têm também menor umidade e são, assim, os mais importantes para a geomorfologia costeira do Ceará, pois mobilizam uma maior quantidade de sedimentos durante o período em que predominam, orientando a direção de migração das dunas (PINHEIRO e SALES, 2007; CLAUDINOSALES, 1993).

No Estado do Ceará, os ventos se apresentam enquanto um dos elementos climáticos mais importantes. Têm velocidades médias de $5,5 \mathrm{~m} / \mathrm{s}$, dominando os alísios de SE, E e NE (FUNCEME, 2018). Estes são naturalmente impulsionadores de sedimentos para edificação de dunas, utilizando estoques sedimentares das zonas de estirâncio, de berma e das praias.

Do ponto de vista da dinâmica litorânea, tem-se que as ondas têm direção dominante E/SE, com altura média significativa de 1,1 m. Dominam as ondas tipo "sea", formadas no local, com ocorrências, sobretudo entre dezembro e março das ondas do tipo "swell", formadas no hemisfério Norte (PINHEIRO et. al., 2015). As ondas, associadas às variações de marés, são responsáveis pela escultura das formas litorâneas, notadamente das falésias, ambientes em processo natural de recuo pela erosão (PINHEIRO et al., 2015).

As correntes de deriva litorânea são responsáveis pela manutenção do equilíbrio dinâmico das praias, como verdadeiros rios de areia que se locomovem suavemente na zona litorânea. A corrente longitudinal ou deriva litorânea, possui velocidade média da ordem de $0,5 \mathrm{~m} / \mathrm{s}$ e realiza um transporte dominante de leste em direção a oeste (MAIA, 1998). O regime de marés é mesotidal, ou seja, com marés altas não muito elevadas. As marés são semidiurnas, isto é, duas marés altas por dia, com amplitude de marés da ordem de $3,7 \mathrm{~m}$ e média de marés altas de 2,7m (e.g. MAIA, 1998; PINHEIRO et al., 2015).

Tratando da hidrografia, tem-se que a grande bacia hidrográfica do Rio Jaguaribe (Figura 1) é formada por padrão dendrítico ou arborescente, apresentando desenvolvimento semelhante à configuração de ramos de uma árvore. No entanto, podem ser encontrados também os padrões paralelos (fluxos d'água fluindo quase paralelamente uns aos outros) e retangulares (caracterizados pelo reticulado ortogonal), dentre outros (IPLANCE, 1997). Como principais afluentes destacam-se os rios Banabuiú, Palhano e Riacho do Sangue na 
margem esquerda. Na margem direita, os principais são os rios Salgado e Cariús; todos os demais são de pequena a média extensão (GATTO, 1999).

Quanto aos solos, verifica-se que na planície litorânea ocorrem os neossolos quartzarênicos. São solos muito profundos, excessivamente drenados, ácidos e com fertilidade natural muito baixa. Seu uso limita-se pela acidez excessiva, a susceptibilidade à erosão e a baixa retenção de umidade, estando associados às feições de praia, campos de dunas móveis, campo de dunas fixas e paleodunas e à planície flúvio-marinha. (PEREIRA e SILVA, 2005).

Nos tabuleiros costeiros arenosos e areno-argilosos estão associados, respectivamente, aos neossolos quartzênicos e aos argissolos vermelho-amarelos distróficos e latossolos amarelos distróficos. Os argissolos vermelho-amarelos são solos variando de rasos a profundo. Apresentam textura média ou argilosa, moderadamente ou imperfeitamente drenados, com fertilidade natural de média a baixa. Os latossolos são solos muito profundos, bem drenados, apresentam textura arenosa ou areno- argilosa, com fertilidade natural variando de média a baixa (PEREIRA e SILVA, 2005).

A planície fluvial é representada pela planície aluvial do baixo curso do Rio Jaguaribe, onde se apresenta associação de neossolos flúvicos, planossolos e vertissolos. Os neossolos flúvicos são solos profundos, mal drenados, muito ácidos, textura indiscriminada e fertilidade natural muito baixa (PEREIRA E SILVA, 2005). Suas limitações de uso vinculam-se ao excesso de água, à salinização, à drenagem imperfeita e às inundações. Os planossolos são rasos a moderadamente profundos, mal drenados, com textura também indiscriminada e fertilidade natural média à baixa com problema de sais. Já os vertissolos são solos rasos, mal drenados, textura argilosa e fertilidade natural alta. As suas limitações de uso estão conectadas com a imperfeição na drenagem, à baixa permeabilidade e a susceptibilidade à erosão (SOUZA, 2000).

Do ponto de vista florístico, coloca-se que a unidade de vegetação pioneira psamófila estende-se ao longo do litoral estudado, nos ambientes de pós-praia e dunas móveis, onde há o predomínio de terrenos arenosos (MORO et al., 2015). Faz parte dessa unidade espécies herbáceas e gramíneas, tendo destaque, a salsa (Ipomea assarifolia), a salsa de praia (Ipomoea pes-caprae), o pinheirinho da praia (Remirea marítima), entre outros. Essas espécies são de elevada importância, pois atuam como obstáculos no transporte eólico das areias (FIGUEIREDO, 1997).

A vegetação subperenefólia de dunas desenvolve-se pelas superfícies das dunas mais antigas e estabilizadas que, anteriormente, foram colonizadas pela vegetação pioneira, sendo predominantemente arbustivas. Tal vegetação possui papel fundamental na estabilização das 
areias, diminuindo o avanço dos sedimentos dunares para o interior. Entre as espécies mais característicos dessa unidade vegetacional destacam-se o cajueiro (Anacardium occidentale), juazeiro (Zizyphus joazeiro), goiabinha (Psidium sp.), murici (Byrsonima sp.), angélica (Guettarda angélica), dentre outros. (MORO et al., 2015).

A vegetação de mangue estende-se pelas áreas de inundação das planícies flúviomarinhas, correspondentes ao ecossistema denominado manguezal. São poucas espécies que, em conjunto, abastecem a base nutritiva deste produtivo ambiente (POR, 2004). Segundo Monteiro (2005), as principais espécies de vegetação que ocorrem, são a Rhizophora mangle, Avicennia schaueriana e germinans, Laguncularia racemosa, e Conocarpus erectus.

A vegetação de várzea estende-se ao longo do médio e baixo curso do rio. Há um predomínio de um estrato mais elevado ocupado por carnaubeiras (Copernicia cerifera). No estrato arbustivo-arbóreo são encontradas espécies como o marmeleiro (Croton sp.), a jurema (Mimosa tenuiflorar) e o mufumbo (Combretum leprosum), entre outros. (MONTEIRO, 2005).

A vegetação subcaducifólia de tabuleiro estende-se por praticamente todo o tabuleiro costeiro do estado do Ceará. Há um predomínio de espécies arbóreas, porém acompanhadas de um estrato arbustivo e outro herbáceo. É representada por espécies como jenipapo bravo (Tacayena sp.), juazeiro (Zizyphus joazeiro), mandacaru (Cereus sp.), pau ferro (Cássia ramiflola), ameixa (Ximenia americana), angélica (Guettarda sp.), imbaúba (Cecropia sp.), cajueiro (Anacardium occidentale) e croata (Bromélia sp.) (FIGUEIREDO, 1997; MORO et al., 2015).

\section{ANÁLISE E COMPARTIMENTAÇÃo GEOMORFOLÓGICA DA ÁREA DE ESTUDO}

A compartimentação geomorfológica aqui apresentada indica a existência de um conjunto de feições com litologias variadas. Além do ambiente estuarino em si e sua planície flúvio-marinha com manguezais, são encontradas as seguintes unidades de relevo: planície litorânea com suas subunidades (faixa de praia, barreiras, áreas de deflação, campos de dunas atuais móveis e subatuais fixas, falésias) e tabuleiros costeiros. A Figura 4 ilustra os principais elementos que compõem esses compartimentos geomorfológicos. Existem outros elementos de menor dimensão e, portanto, sem representatividade na escala do mapa, os quais serão tratados em conjunto nos itens a seguir. 


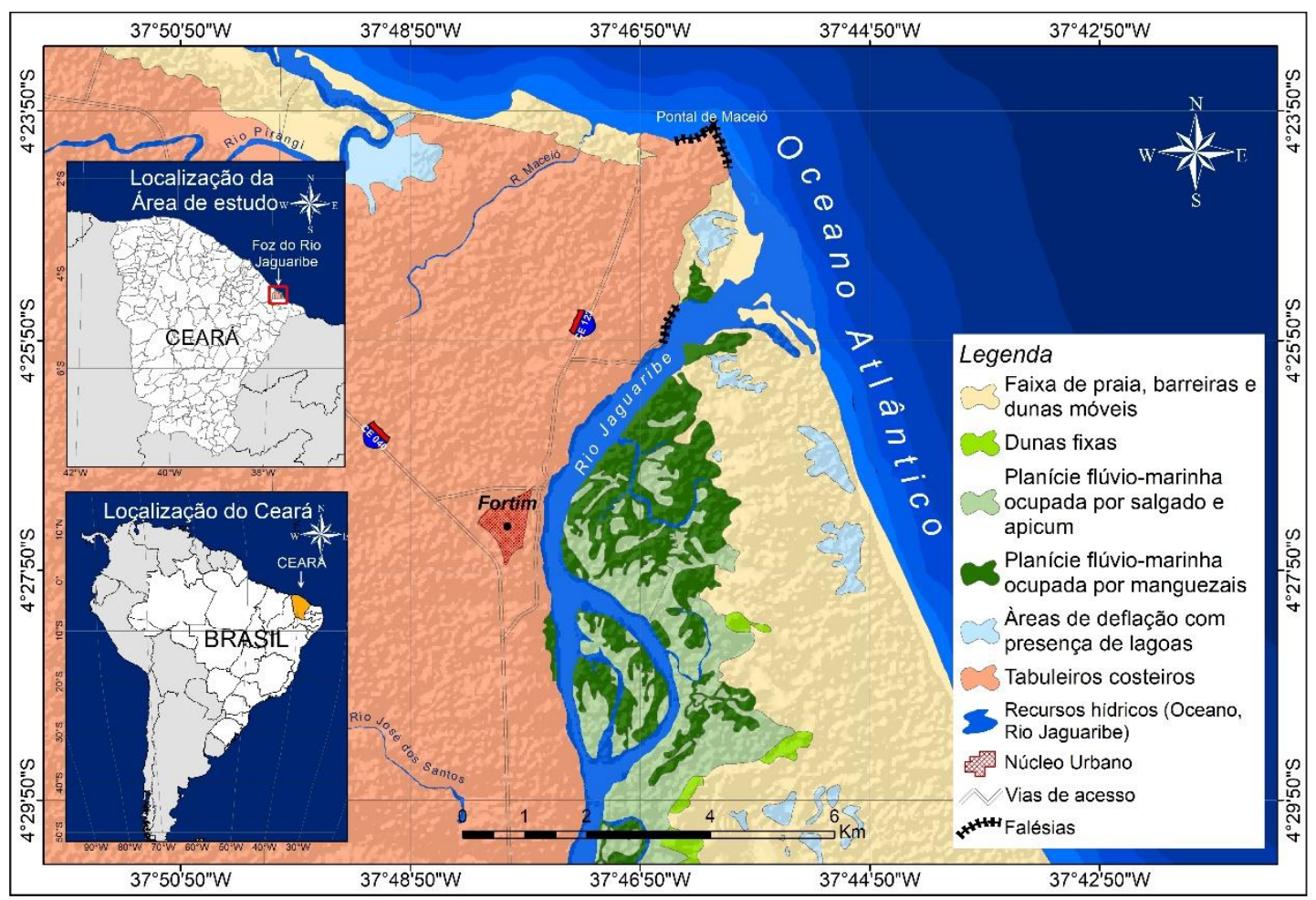

Figura 4: Mapa geomorfológico sintetico da foz do Rio Jaguaribe e áreas costeiras adjacentes.

\subsection{Planície Litorânea}

De forma geral, no Estado do Ceará, a planície litorânea apresenta morfogênese subordinada a processos de acumulação e erosão. As formas de relevo mais típicas dessa unidade ao longo de toda a zona costeira do Ceará são: a praia, o pós-praia, dunas atuais e subatuais, falésias, sistemas lacustres, "beachrocks" (rochas de praia), barras litorâneas, além da existência de afloramentos do embasamento cristalino. Ao longo do processo evolutivo, as planícies litorâneas foram e continuam sendo modeladas pela ação dos ventos, correntes, marés e ondas (CLAUDINO SALES, 2002; 2016; VIDAL 2006).

A faixa de praia ou estirâncio representa a porção de terra coberta e descoberta periodicamente pelas águas, acrescidas das faixas subseqüentes de material detrítico, tal como areias, cascalhos, seixos e pedregulhos, até o limite onde se inicie a vegetação natural ou, em sua ausência, onde comece outro elemento (CEARÁ, 2006). Esse outro elemento é o póspraia ou berma - porção horizontal mais ao continente constituído por material arenoso e formado pela ação das ondas e em condições do nível do mar atual. Em geral, no nosso estado, apresenta-se bastante estreita e margeando toda a faixa de praia (MAIA, 1993).

$\mathrm{Na}$ área de pesquisa, na margem direita da foz do rio Jaguaribe nota-se uma extensa 
faixa de praia desde Canoa Quebrada à desembocadura do rio Jaguaribe. São definidas as faixas de praia e berma. A ocupação nesse trecho é praticamente inexistente, conservando assim suas características naturais (Figura 6).

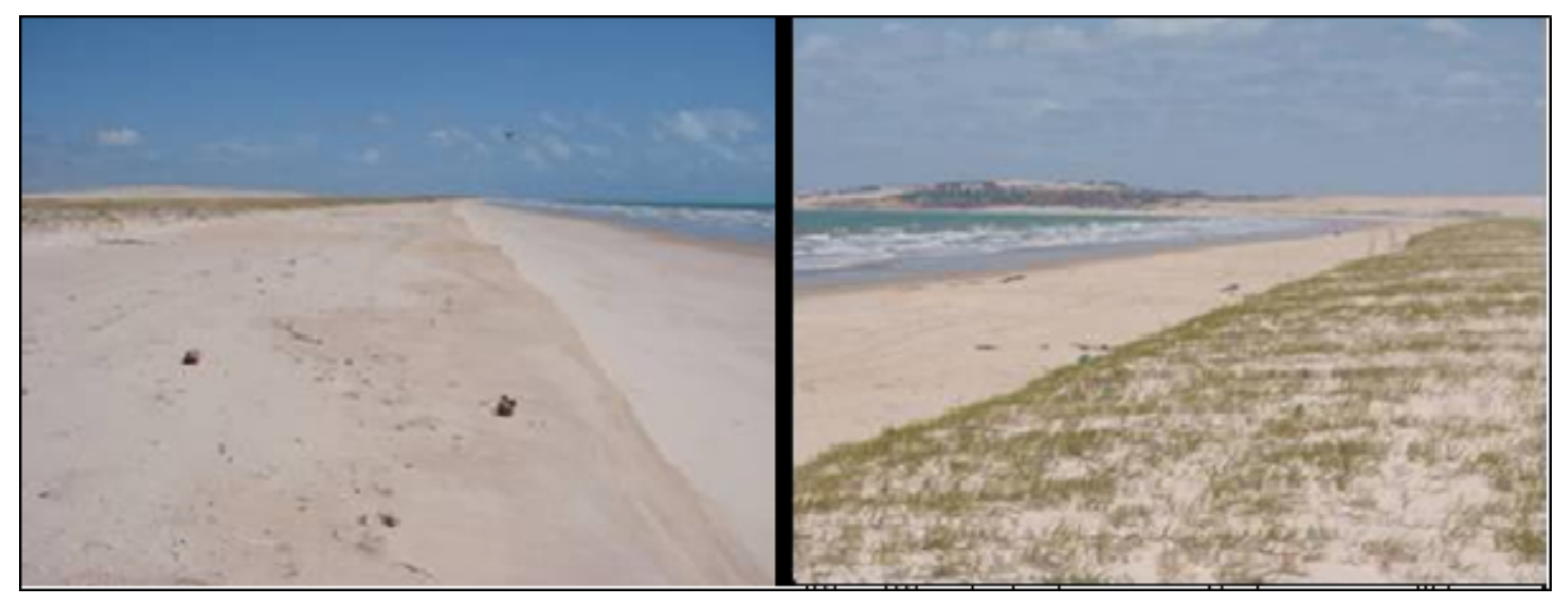

Figura 5: Margem direita foz do rio Jaguaribe, extensa faixa de praia e pós-praia, delimitada em direção ao continente por duna frontal.

Dispostas paralelamente às praias em vários trechos do litoral cearense encontram-se as barreiras. São formadas pela energia das ondas, sendo necessário para isto, grande suprimento de areias e lugar de acomodação. De acordo com a tipologia (CLAUDINOSALES e PEULVAST, 2006), podem ser classificadas enquanto ilhas barreiras, cordões litorâneos, duplas flechas fluviais e flechas litorâneas. Na área de estudo, elas ocorrem na forma de barreiras do tipo spits (Figura 6).

Em direção ao continente, a partir do berma e até a base dos campos de dunas, ocorre a planície de deflação (Figura 7). São superfícies planas e horizontais, ou ligeiramente inclinadas, que trabalhadas pelo vento fornecem sedimentos para a edificação das dunas (CEARÁ, 2006). Com efeito, as planícies de deflação formam superfícies alongadas e relativamente extensas e planas (CEARÁ, 2006). Esta planície vai sendo erodida e rebaixada pelo vento, até atingir as proximidades do nível do lençol de água, quando então lagoas interdunares perenes e intermintentes são formadas. 


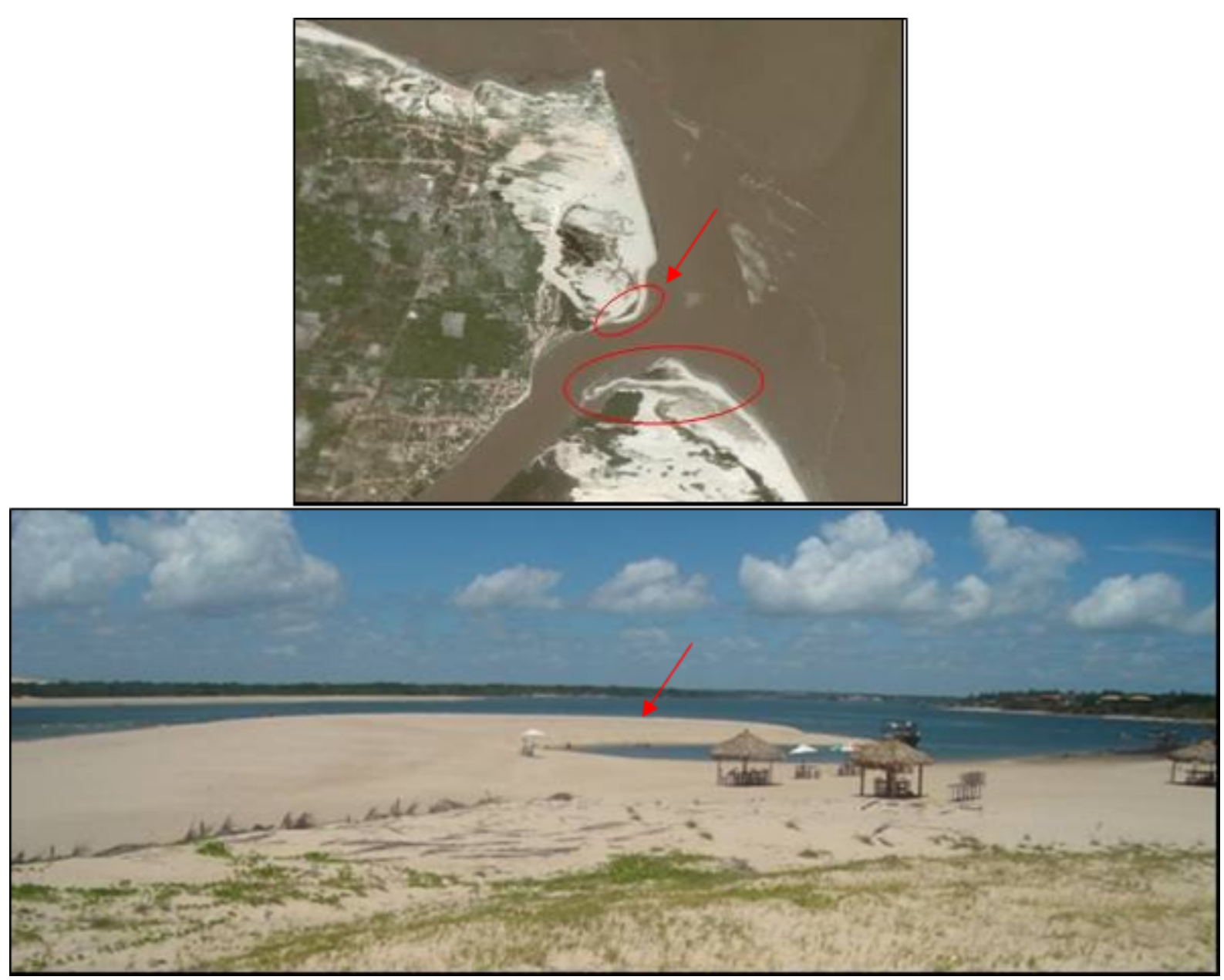

Figura 6: Spit localizado na margem esquerda da desembocadura fluvial do rio Jaguaribe.

As dunas são depósitos de sedimentos tipo areia, acumulados pelo vento (agente único). Para a sua formação é fundamental que a velocidade do vento e a disponibilidade de areias praiais de granulometria fina sejam adequadas para o transporte eólico (MUEHE, 1994). Para o seu desenvolvimento, é necessário que as areias de porções secas das praias sejam sopradas em direção ao continente até que a energia do vento se dissipe ou uma barreira física - por exemplo, a vegetação -, cause a deposição dos grãos de areia (HESP, 2002).

As grandes famílias de formas dunares no Estado do Ceará são as móveis, fixas, semifixas e as formas de deflação (e.g. CLAUDINO SALES, 2002). 


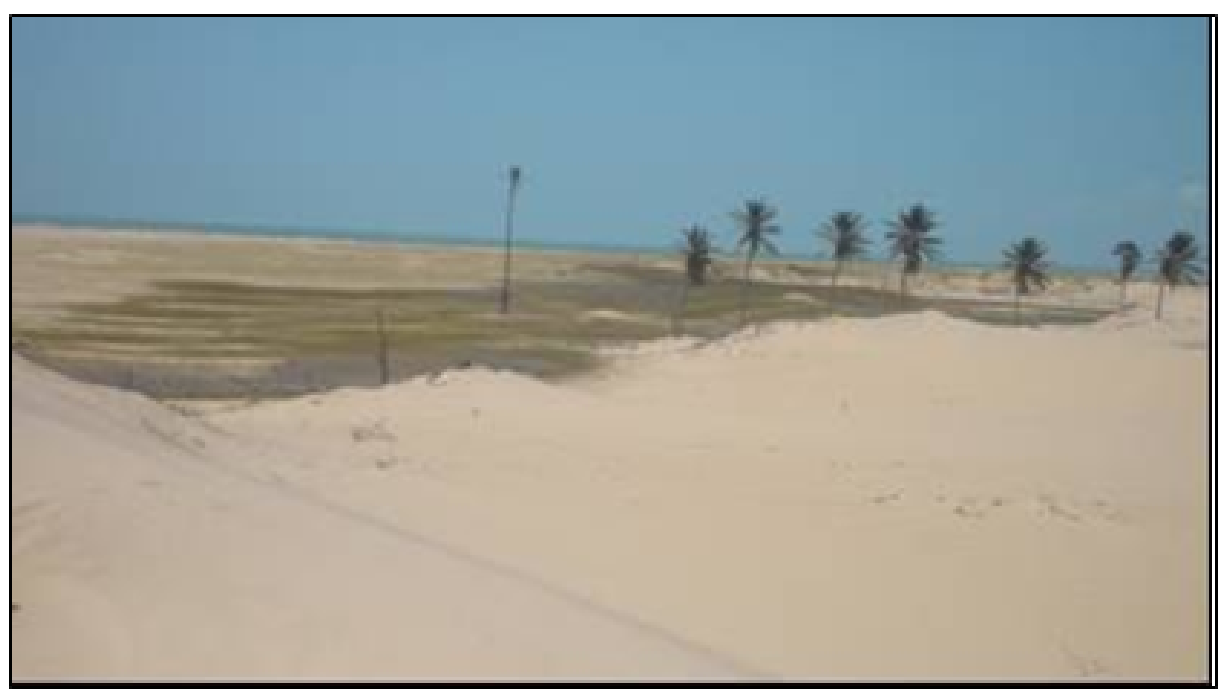

Figura 7: Planície de deflação na margem direita da desembocadura fluvial do Jaguaribe/Ceará.

As dunas móveis não apresentam cobertura vegetal, ou ocorrem em sua superfície apenas espécies pioneiras e de pequeno porte. São instáveis e migratórias. Podem ser classificadas em: dunas longitudinais (dispostas paralelamente ao vento principal, que tem direção preponderante de $\mathrm{E}$ - SE); barcanas (com formato de croissant com os braços voltados ao vento); parabólicas (forma de croissant com braços contrários ao vento); dunas de arraste ou "trailing dunes" (são traços de migração de dunas); barcanóides transversais (ocorrem em conjunto); e os lençóis de areia ou os "sandsheets" (acumulações de areia livre sem forma definida) (e.g. CARVALHO e CLAUDINO-SALES, 2017).

As dunas semifixas, apresentam certo grau de estabilidade mas possuem dinâmica. Podem ser dunas frontais, que representam as primeiras dunas que se formam a partir da faixa de praia e preserva a antepraia do processo erosivo (ver figura 5), ou nebkas, que são montículos cobertos por vegetação psamófila na planície costeira. Cita-se ainda as parabólicas, que possuem o "front" mais ou menos móvel e braços semifixos, contando com presença de lagoas entre dunas nas áreas de deflação (e.g. CLAUDINO-SALES, 2005).

As dunas fixas são os depósitos que não possuem dinâmica. São os depósitos eólicos recobertos por vegetação de porte arbóreo/arbustivo, sem forma definida, pois a cobertura vegetal e solo mascaram as formas. São dunas inativas, paleoformas, que representam a maior parcela das dunas do Ceará. Ocorrem ainda as parabólicas hairpin, em formato de grampo de cabelo, que se acredita que devam evoluir a partir de dunas parabólicas semifixas e blowouts. (HESP, 2002).

As dunas desempenham um papel ambiental importante, pois são formadas por sedimentos bem classificados, areias finas a médias, criando assim um alto grau de 
permeabilidade, permitindo a infiltração e o abastecimento do lençol freático. Além disso, essas formas fornecem sedimentos para a zona costeira e litorânea, construindo um balanço sedimentar fundamental, já que a falta de sedimento leva à erosão e o excesso de sedimentos ao assoreamento. Assim, as dunas vêm equilibrar essa dinâmica.

A margem direita da desembocadura do rio Jaguaribe possui o campo de dunas móveis contínuo mais expressivo do estado do Ceará. São observadas barcanóides, shansheets, dunas de precipitação (isto é, dunas transgressivas, que migram recobrindo qualquer obstáculo no terreno), rebdous (morro dunar vegetalizado esculpido pela deflação, de acordo com CLAUDINO-SALES, 2002, 2016; Figura 8) e as dunas frontais (ver figura 5).

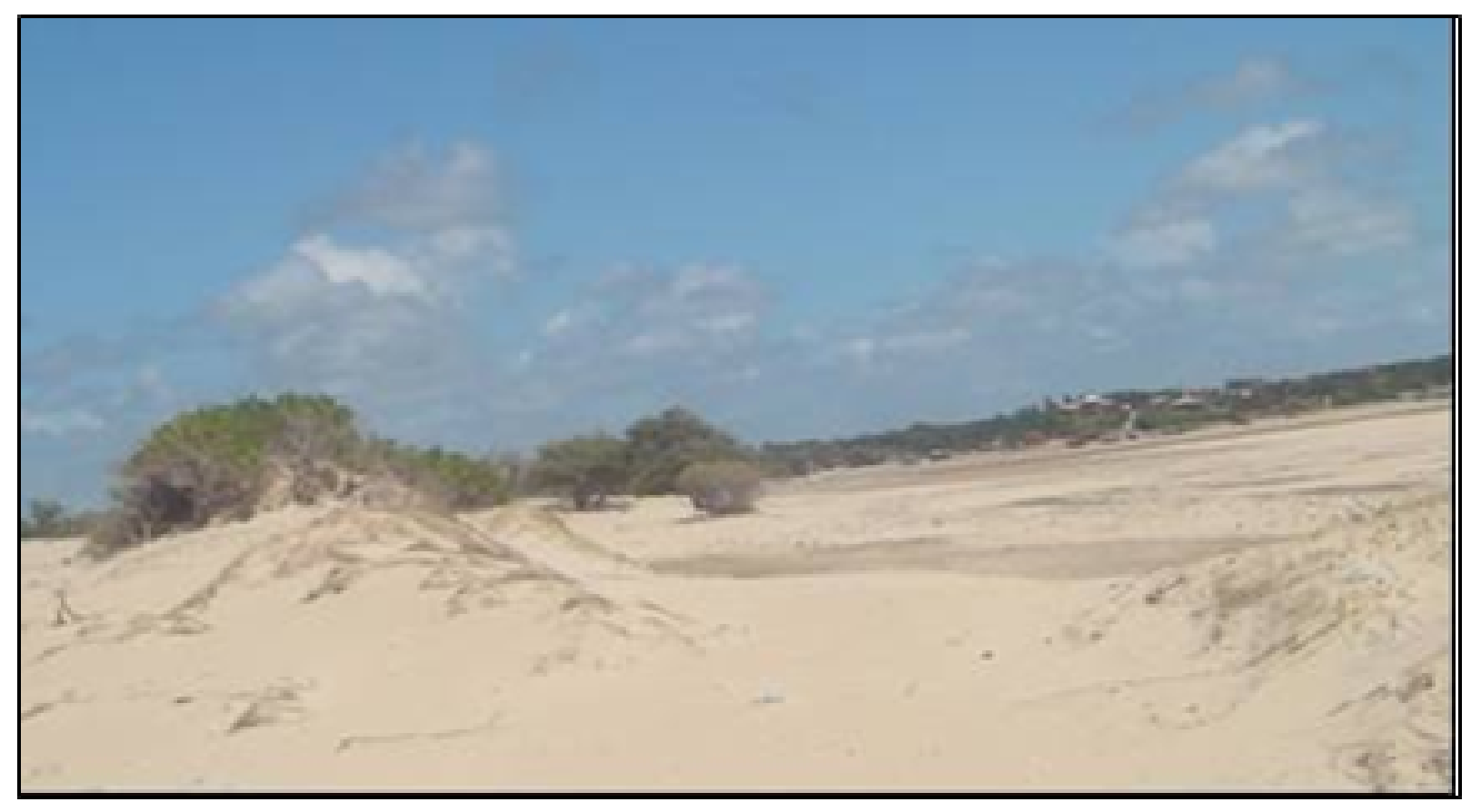

Figura 8: Duna rebdou visualizada na margem direita da foz do rio Jaguaribe.

Podem ser definidas duas gerações de dunas (PEDROSA, 2016). Uma mais recente que está em atividade migratória, se precipitando sobre as áreas de manguezal (Figura 9A) e avançando sobre uma geração mais antiga, já estabilizada (Figura 9B). Esses depósitos eólicos integram a "Área de Proteção Ambiental de Canoa Quebrada". A APA é uma Unidade de Conservação - UC. A UC de Canoa Quebrada está incluída na categoria de Unidade de Uso Sustentável, nas quais é permitido o uso sustentável de parcela de seus recursos naturais, em compatibilidade com a conservação da natureza (PEDROSA, 2016).

As Unidades de Conservação são definidas enquanto espaço territorial e seus recursos ambientais, incluindo as águas jurisdicionais, com características naturais relevantes. São 
legalmente instituídos pelo Poder Público, com objetivos de conservação e limites definidos, sob regime especial de administração, aos quais se aplicam garantias adequadas de proteção (definição dada pela Lei $n^{\circ}$. 9.985, de 18 de julho de 2000, que institui o Sistema Nacional de Unidades de Conservação da Natureza - SNUC).

A Área de Proteção Ambiental é uma área em geral extensa. Possui certo grau de ocupação humana, dotada de atributos abióticos, bióticos, estéticos ou culturais especialmente importantes para a qualidade de vida e o bem-estar das populações humanas, e tem como objetivos básicos proteger a diversidade biológica, disciplinar o processo de ocupação e assegurar a sustentabilidade do uso dos recursos naturais (SNUC, 2000).

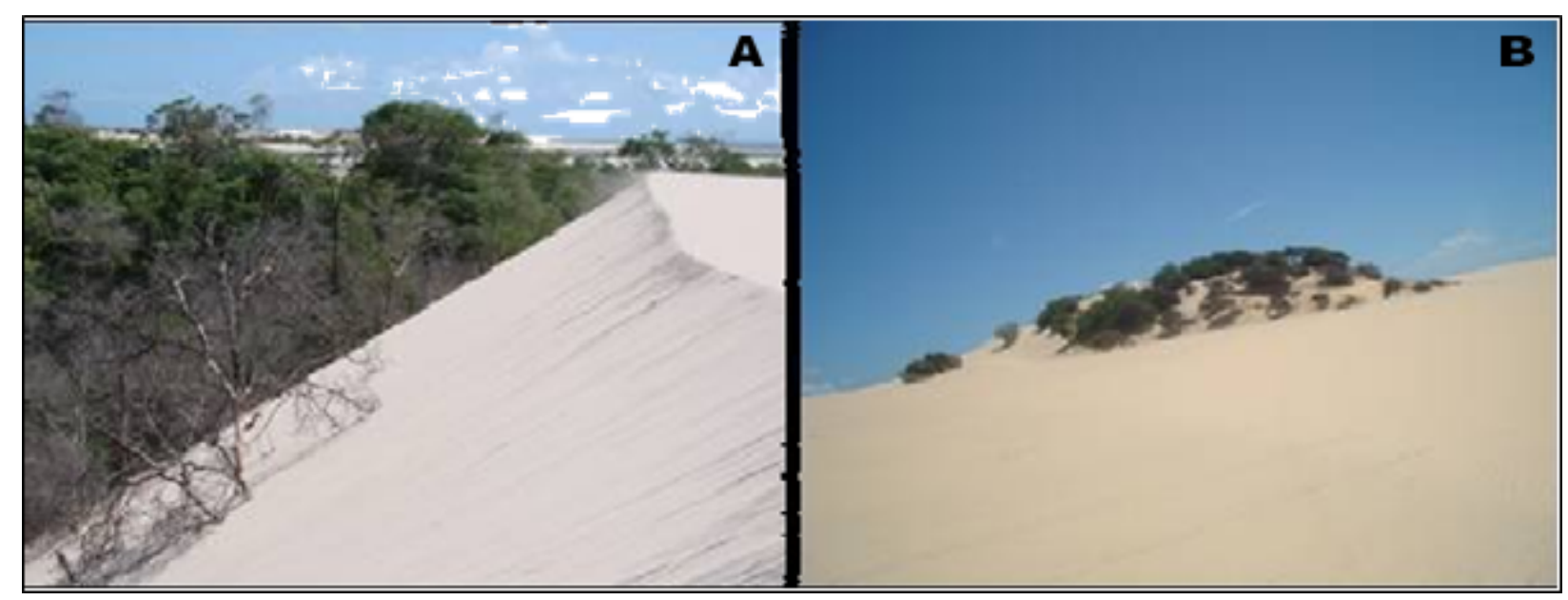

Figura 9: Na figura A vê-se uma duna de precipitação no contato com o manguezal do rio Jaguaribe. A figura B apresenta sandsheets recobrindo dunas fixas do tipo rebdou mais antigas no campo de dunas localizados nas proximidades da desembocadura fluvial do rio Jaguaribe.

A APA de Canoa Quebrada é uma das 62 (sessenta e duas) UC’s distribuídas pelo Estado do Ceará (SEMACE, 2018). A administração desta APA é de responsabilidade municipal, tendo sido criada pela Lei n 40/98 de 20 de março de 1998, com uma área de 4000 ha, localizando-se a nordeste do município de Aracati. Abrange unidades do ecossistema costeiro e do complexo vegetacional litorâneo (PEDROSA, 2016).

Outra feição bem marcante no litoral do estado são as lagoas, as quais podem ser classificadas em lagunas (formadas por água marinha) e costeiras (compostas pela interação das águas continentais fluviais e freáticas) (CLAUDINO SALES, 2002). Na área elas estão representadas na planície de deflação. Nestas superfícies predomina a remoção de sedimentos pelos processos eólicos e o afloramento do lençol freático nas depressões de deflação. Neste estágio, a umidade, que pode ascender, inclusive, por capilaridade (Figura 10), acaba por impedir a continuidade da migração dos sedimentos. Em outros setores, o lençol freático 
garante a existência de lagoas que tendem a serem perenes.

A compartimentacao geoambiental apresentada indica ainda a existência de uma linha de falésias ativas, modeladas em sedimentos Barreiras na margem esquerda do rio, próximo da sua desembocadura (Figura 11). Ocorre, ainda, uma ponta litorânea: o Pontal de Maceió (para localização, ver figura 2), no qual foram modeladas falésias ativas (Figura 12).

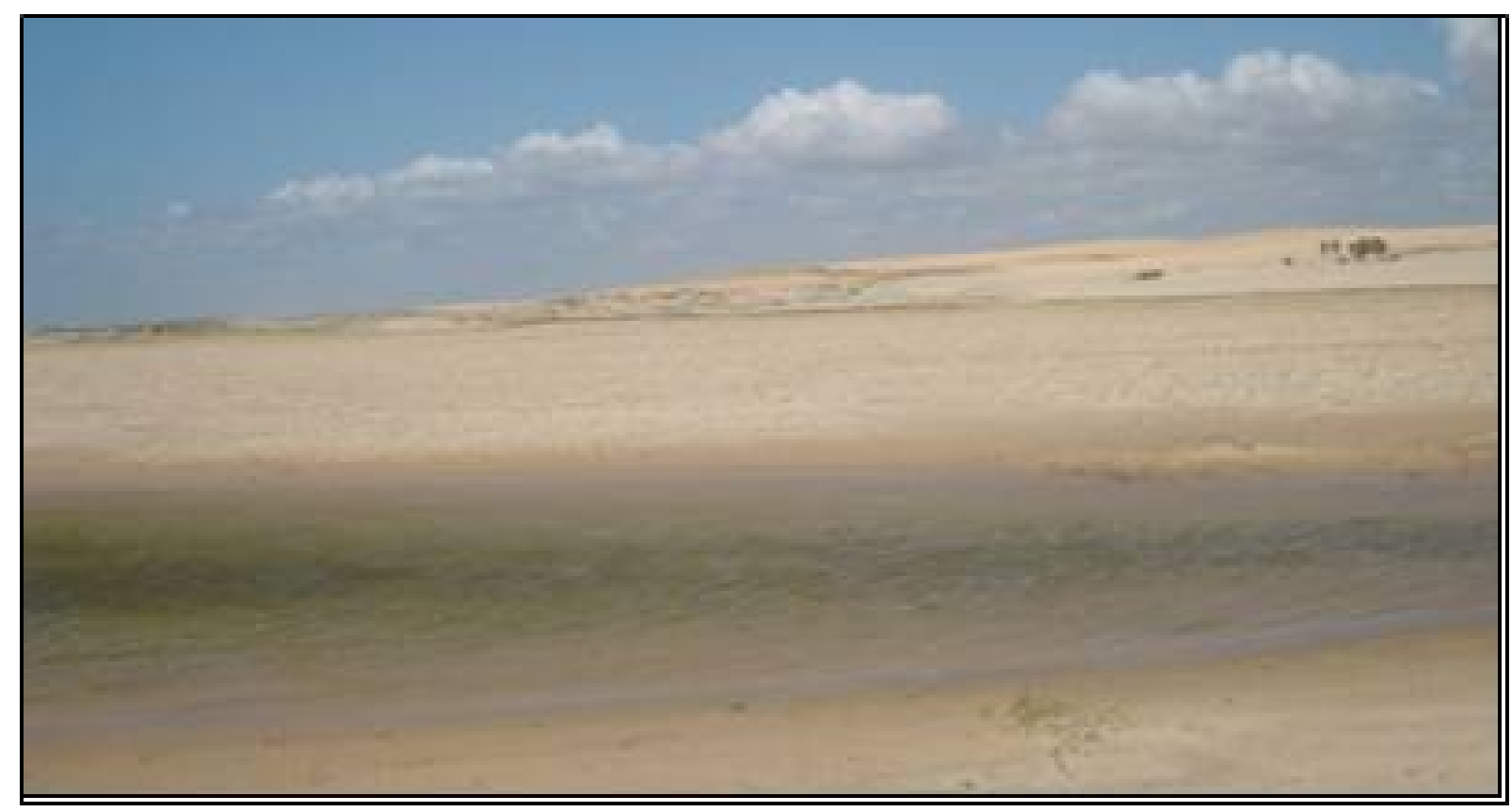

Figura 10: Ocorrência de lagoas na planície de deflação, margem direita da desembocadura fluvial do rio Jaguaribe.

As pontas litorâneas são protuberâncias em direção ao mar. No Ceará, elas podem ser cristalinas, como por exemplo, a ponta do Iguape, Mucuripe, Pecém e Jericoacoara, representantes de locais de ruptura do Gondwana (CLAUDINO SALES, 2005). Podem ser ainda sedimentares, modeladas na Formação Barreiras, na Formação Tibau e em beachrocks. $\mathrm{Na}$ área de pesquisa temos como exemplo exatamente o Pontal do Maceió, que representa o único afloramento em área litorânea da Formação Tibau no Estado do Ceará.

\subsection{Ambiente Estuarino}

É constituído pelo próprio canal do rio e pela vegetação que ocorre em ambos os lados do canal. Neste ambiente, ainda estão incluídos bancos de areia e ilhas, planície de inundação flúvio-marinha, afluentes, gamboas e meandros abandonados com lagoas (CEARÁ, 2006). 
Os estuários compreendem ecossistemas de grande produtividade ecológica e econômica, os quais vêm na atualidade passando por modificações na sua composição geográfica natural (MENEZES et al, 2003). São corpos de água costeiros semifechados, com livre comunicação com o mar, onde a água salgada se mistura com a água doce do rio.

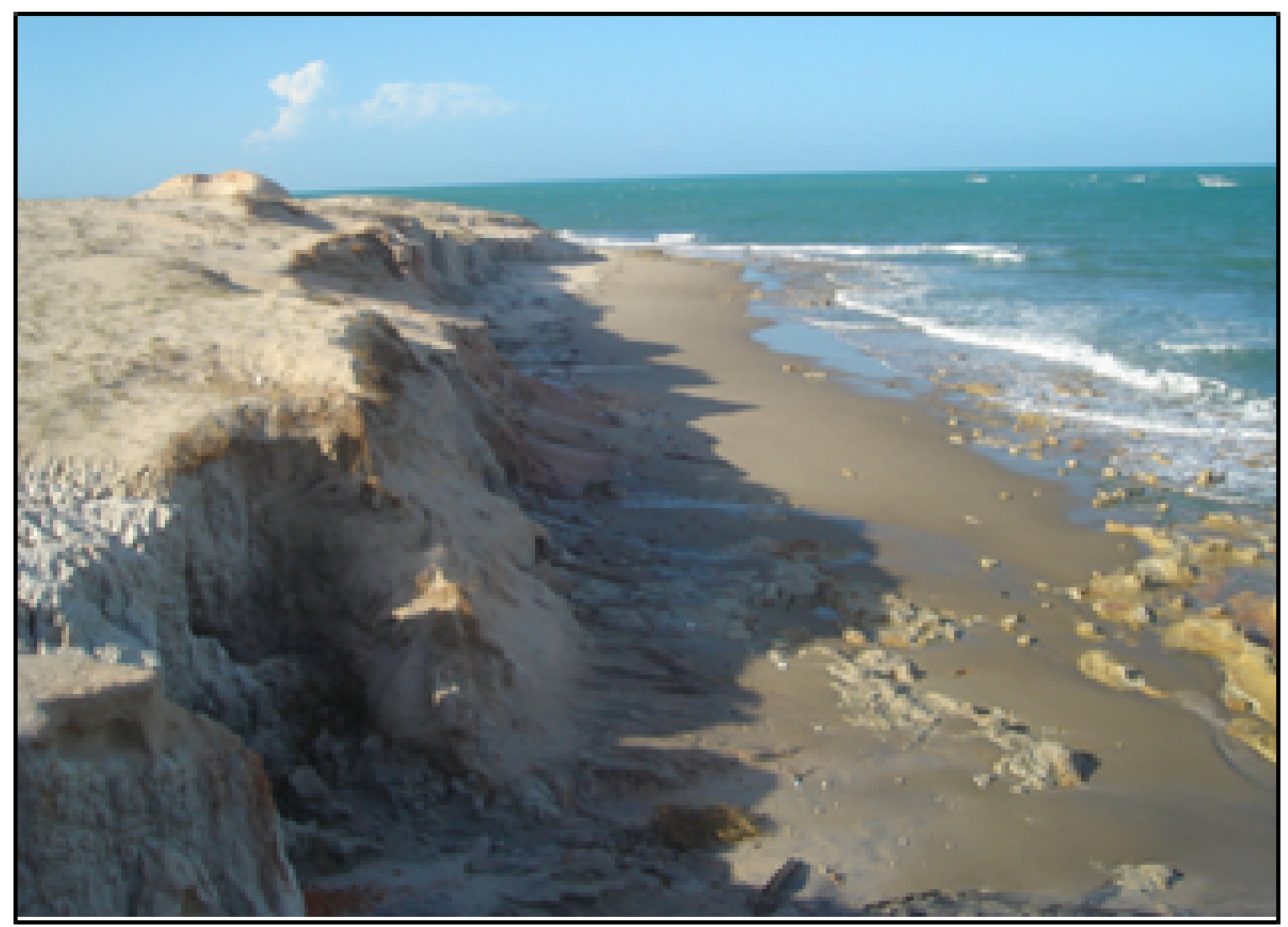

Figura 11: Linha de falésias ativas em sedimentos Barreiras nas proximidades do Pontal de Maceió, margem esquerda foz do rio Jaguaribe.

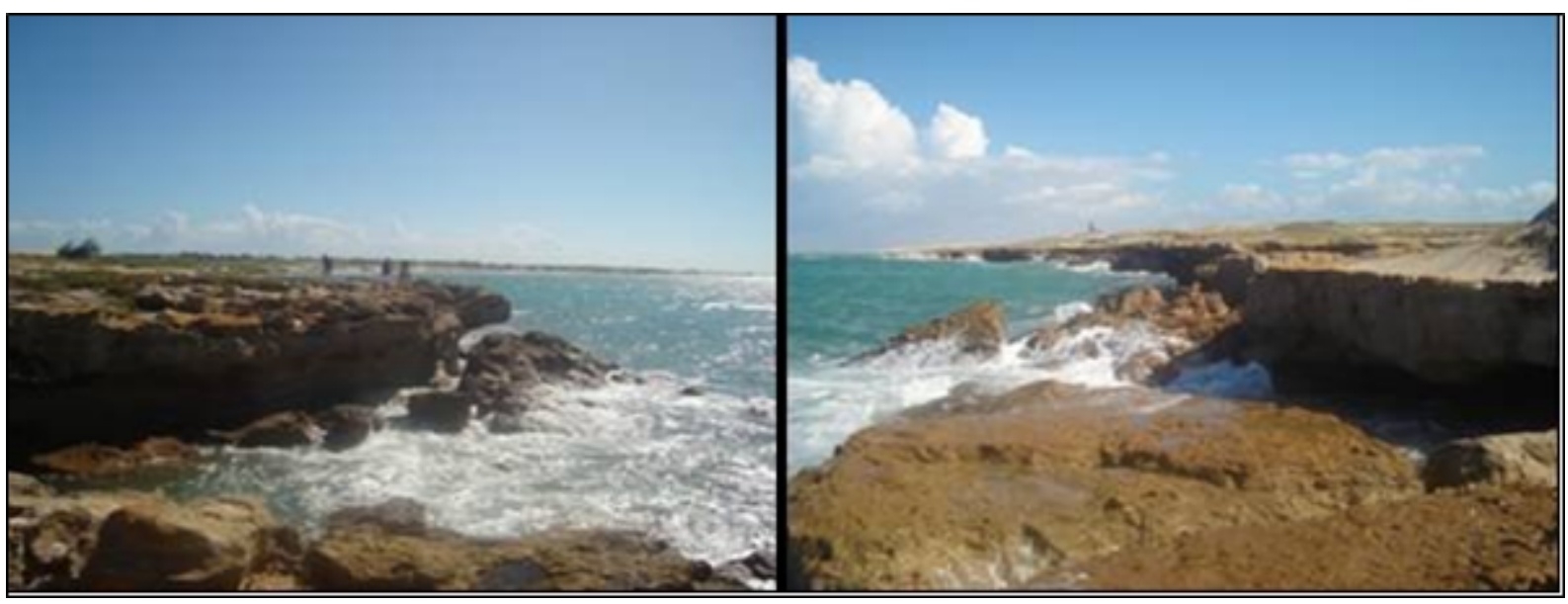

Figura 12: Pontal de Maceió, falésia ativa trabalhada em arenitos da Formação Tibau., situada na margem direita da foz. 
Os estuários são conectados ao oceano por um canal principal e caracterizam-se pela presença da ação da maré por toda sua extensão. Por isso mesmo este termo é derivado da palavra latina aestus e aestuarium que são, respectivamente, o nominativo e o genitivo relativos à maré (MORAIS, 1996). Eles se estendem da foz do rio, ou de uma indentação na costa, até o limite máximo de influência da maré, dividindo o seu curso em três partes - o baixo estuário, que é a região dominada por água do mar; o médio estuário, quando há mistura das águas; e o alto estuário, quando domina a água doce, mas sujeito à influência da maré (e.g. MORAIS, 1996).

Alguns dos estuários atuais podem até se transformarem em deltas, dependendo da taxa de sedimentação que possuam. Apenas os que encontram águas costeiras sob ação intensa de marés e ondas suficientemente capazes de dispersar os sedimentos permanecem, de fato, como estuários. Dependendo da amplitude da maré e da descarga do rio, fatores essenciais que determinam até que ponto a maré pode penetrar à montante, os estuários se classificam em três tipos principais: são os de cunha salina, os parcialmente misturados e os bem misturados (MORAIS, 1996).

Entendida muito mais que como a parte terminal de um rio, ou o encontro do rio com o oceano, o sistema estuarino associa unidades geoambientais de extrema importância - trata-se da planície flúvio-marinha ocupada por manguezais (Figura 13) e por salgados e/ou apicuns.

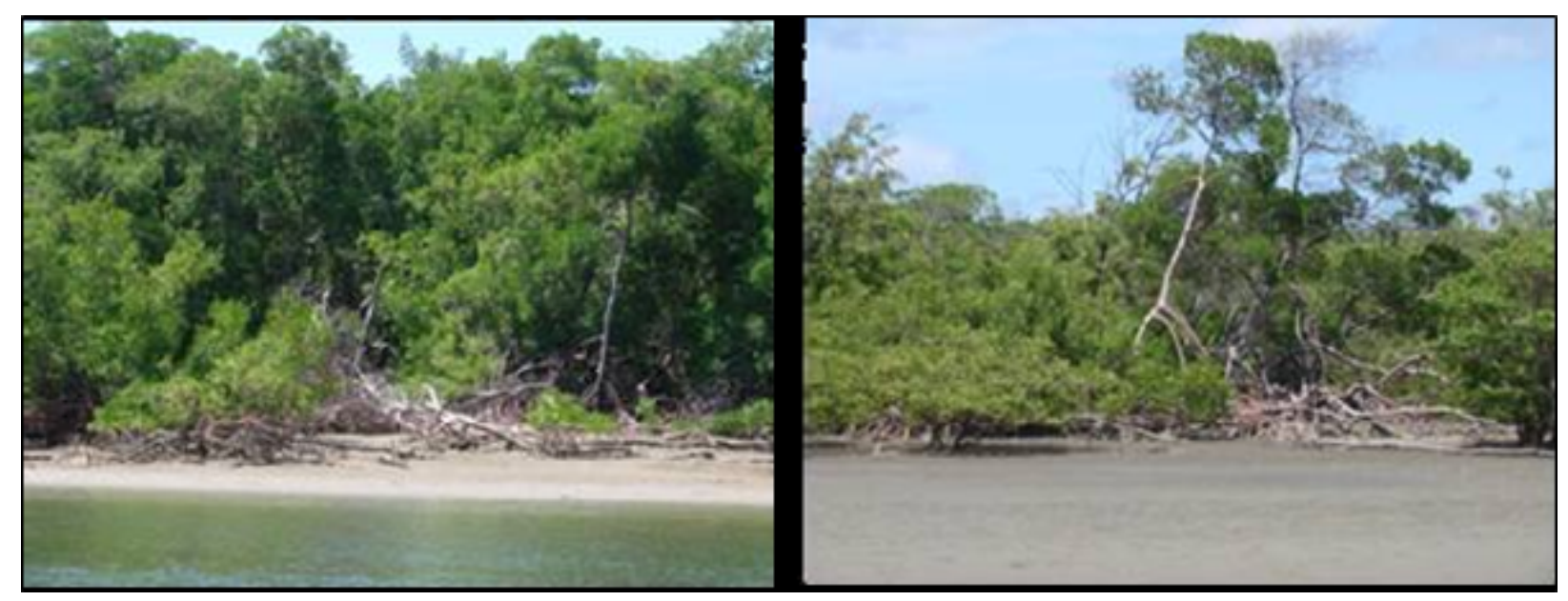

Figura 13: Planície flúvio-marinha ocupada por manguezal, na margem direita do Rio Jaguaribe.

A planície flúvio-marinha é a superfície plana de um estuário, que se situa entre o nível médio da maré baixa de sizígia e o nível médio de maré alta equinocial (MELLO, 2005; CEARÁ, 2006).

As porções mais baixas são cobertas, pelo menos duas vezes por dia, por água salgada, 
por estarem situadas entre as marés baixa e alta, e são formadas por solo tipicamente argiloso, rico em matéria orgânica e mostram-se ocupadas pelos mangues. As áreas topograficamente mais elevadas que as dos manguezais e que são atingidas pelas águas marinhas apenas duas vezes no período de um mês, durante as marés de sizígia, são reconhecidas com "salgados" ou apicuns. Estas duas áreas compõem uma unidade geoambiental denominada de planície flúvio- marinha (LEAL, 2003).

Dessa maneira, as áreas ocupadas por apicum são alagadas periodicamente pelas oscilações de maré, que deixam sobre seu solo arenoso um tapete de fitoplâncton (algas e bactérias), que atuam como início da cadeia alimentar que mantém todo o ecossistema. $\mathrm{O}$ apicum quase não tem vegetação, no entanto, ele evolui e é tomado por vegetação de mangue na dinâmica que move as relações entre os componentes do ecossistema manguezal. Apresenta-se ainda como uma formação de transição entre o manguezal e ecossistemas adjacentes (MELLO, 2005; CEARÁ, 2006).

De acordo com a Resolução no. 303/2002, do Conselho Nacional do Meio Ambiente (CONAMA), o ecossistema manguezal é um "ecossistema litorâneo que ocorre em terrenos baixos, sujeitos a ação das marés, formado por vazas lodosas recentes ou arenosas, às quais se associa, predominantemente, a vegetação natural conhecida como mangue, com influência flúvio-marinha, típica de solos limosos de regiões estuarinas e com dispersão descontínua ao longo da costa brasileira, entre os estados do Amapá e Santa Catarina" (MELLO, 2005).

Diversos trabalhos (e.g. SILVA, 1993; MELLO, 2005; GODOY et al., 2018) destacam diversas funções do manguezal, entre elas: fonte de detritos (matéria orgânica) para as águas costeiras adjacentes, constituindo a base da cadeia trófica de espécies de importância econômica e/ou ecológica; área de abrigo, reprodução, desenvolvimento e alimentação de espécies marinhas, estuarinas, límnicas e terrestres; pontos de pouso (alimentação e repouso) para diversas espécies de aves migratórias, ao longo de suas rotas de migração; manutenção da diversidade biológica da região costeira; proteção da linha de costa, evitando erosão da mesma e assoreamento dos corpos d'água adjacentes; controlador de vazão e prevenção de inundações e proteção contra tempestades. Integrando esse ecossistema e desempenhando importantes papéis somam-se as gamboas, os canais de marés e os bancos de areia (Figura 14). 


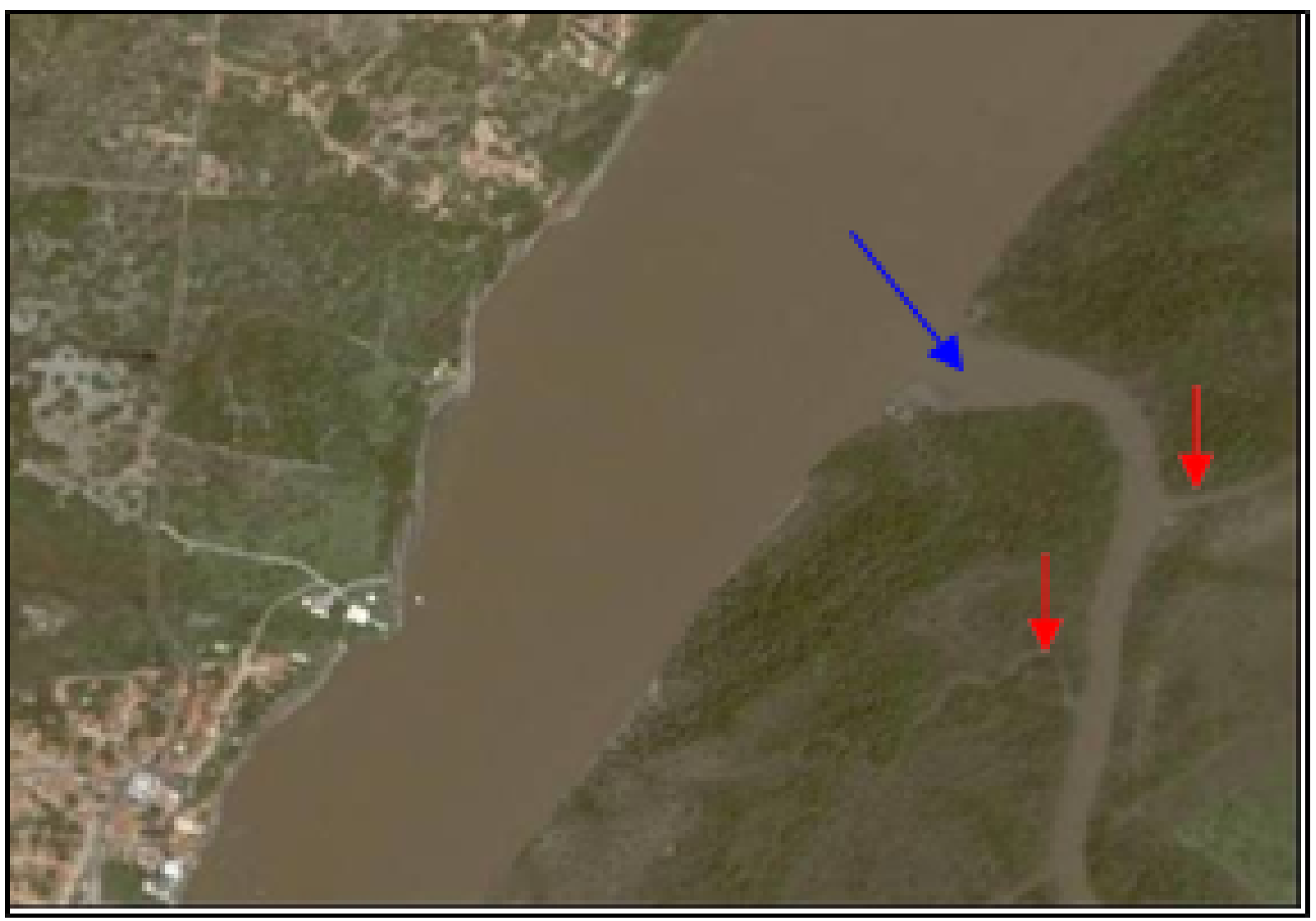

Figura 14: Gamboas e canais de marés, integrantes importantes do ecossistema manguezal, visualizados na Ilha Grande, margem direita da foz do rio Jaguaribe. A seta vermelha indica gamboas e a azul, canal de maré.

As gamboas correspondem a canais estreitos distribuídos em grande quantidade dentro do bosque de mangue, responsáveis pela distribuição e processamento de nutrientes que fornecem a base para a cadeia alimentar do ecossistema (MELLO, 2005).

Os canais de marés são canais mais largos, distribuídos ao longo do estuário e entre os componentes do manguezal. Conduzem as sementes da vegetação de mangue e os nutrientes produzidos ao longo do ecossistema, orientando sua expansão. Os bancos de areias são um volume móvel de sedimentos entre os canais de maré e as gamboas, que pode evoluir para áreas de apicuns e, conseqüentemente, para bosques de mangue (CEARÁ, 2006).

Ilhas flúvio-marinhas também integram a planície flúvio-marinha estudada - trata-se das ilhas do Pinto e do Caldeireiro (Figura 15), situadas a aproximadamente $7 \mathrm{~km}$ da foz do rio, e que juntas ocupam uma área de $23,5 \mathrm{~km}^{2}$. A origem dessas ilhas pode estar ligada à própria sedimentação flúvio-marinha. Apresentam-se colonizadas por denso manguezal. Ocorrem ainda bancos de areia, na forma de volume móvel de sedimentos entre os canais de maré e as gamboas, que podem evoluir para áreas de apicuns e, conseqüentemente, para bosques de mangue. 


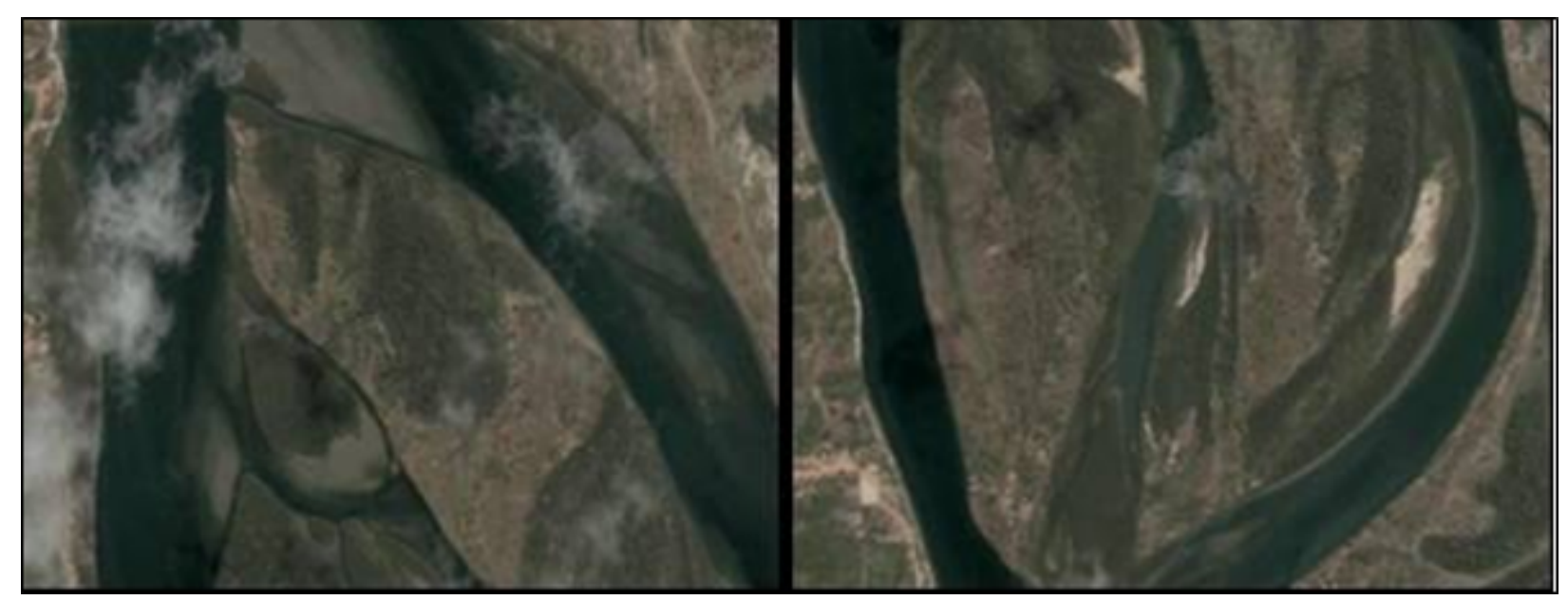

Figura 15: Vista aérea das ilhas flúvio-marinhas do Pinto e do Caldeireiro, desembocadura fluvial do Jaguaribe/Ceará. Fonte: Google Earth, 2018.

\subsection{Tabuleiros Costeiros}

Tratando das formas presentes na faixa costeira, os tabuleiros costeiros possuem morfologia plana, na forma de um glacís suavemente inclinado em direção ao mar, na ordem de $5^{\circ}$ (SOUZA, 1988). Cobertos por mata de tabuleiros sofrem ação dos canais fluviais que dissecam o depósito e criam desníveis que quebram a sua horizontalidade (SOUZA, 2002).

Os tabuleiros costeiros se dispõem da planície litorânea em direção ao interior do continente, constituídos por sedimentos tércio-quartenários da Formação Barreiras. Podem penetrar até cerca de $40 \mathrm{~km}$, em média, para o interior do continente, segundo Souza (1988). $\mathrm{Na}$ margem esquerda do rio Jaguaribe, as cotas dos tabuleiros costeiros variam de 25 a 32 metros, formando um paredão quase contínuo desde as proximidades da desembocadura até Aracati.

Esse paredão fluvial resulta da dissecação da Formação Barreiras pela ação fluvial exercida pelo rio Jaguaribe (Figura 16), e sofre ainda a abrasão produzida por ondas que se formam nos períodos de marés altas. A ocorrência desse paredão na margem esquerda do rio é testemunho da migração permanente do curso fluvial em direção a oeste ao longo do Quaternário, de forma a solapar a base do afloramento da Formação Barreiras no contato com as águas. 


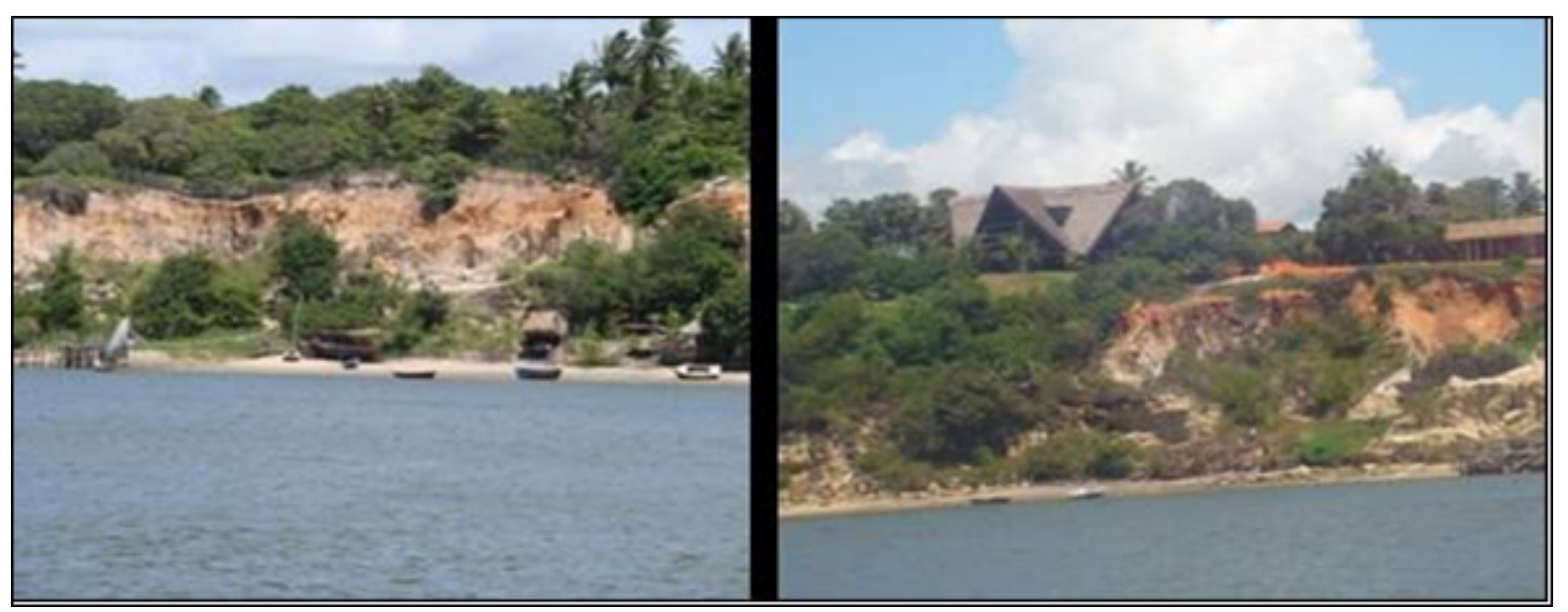

Figura 16: Paredão fluvial trabalhado em sedimentos da Formação Barreiras, margem esquerda do rio Jaguaribe, município de Fortim.

A sede do município de Fortim situa-se sobre os tabuleiros costeiros que constituem a porção mediana da margem esquerda do estuário do rio Jaguaribe. No entanto, próximo à foz deste corpo hídrico, sua porção inferior expõem rochas de natureza arenítica, consolidadas, pertencentes à Formação Tibau (Figura 17) (CEARÁ, 2006).

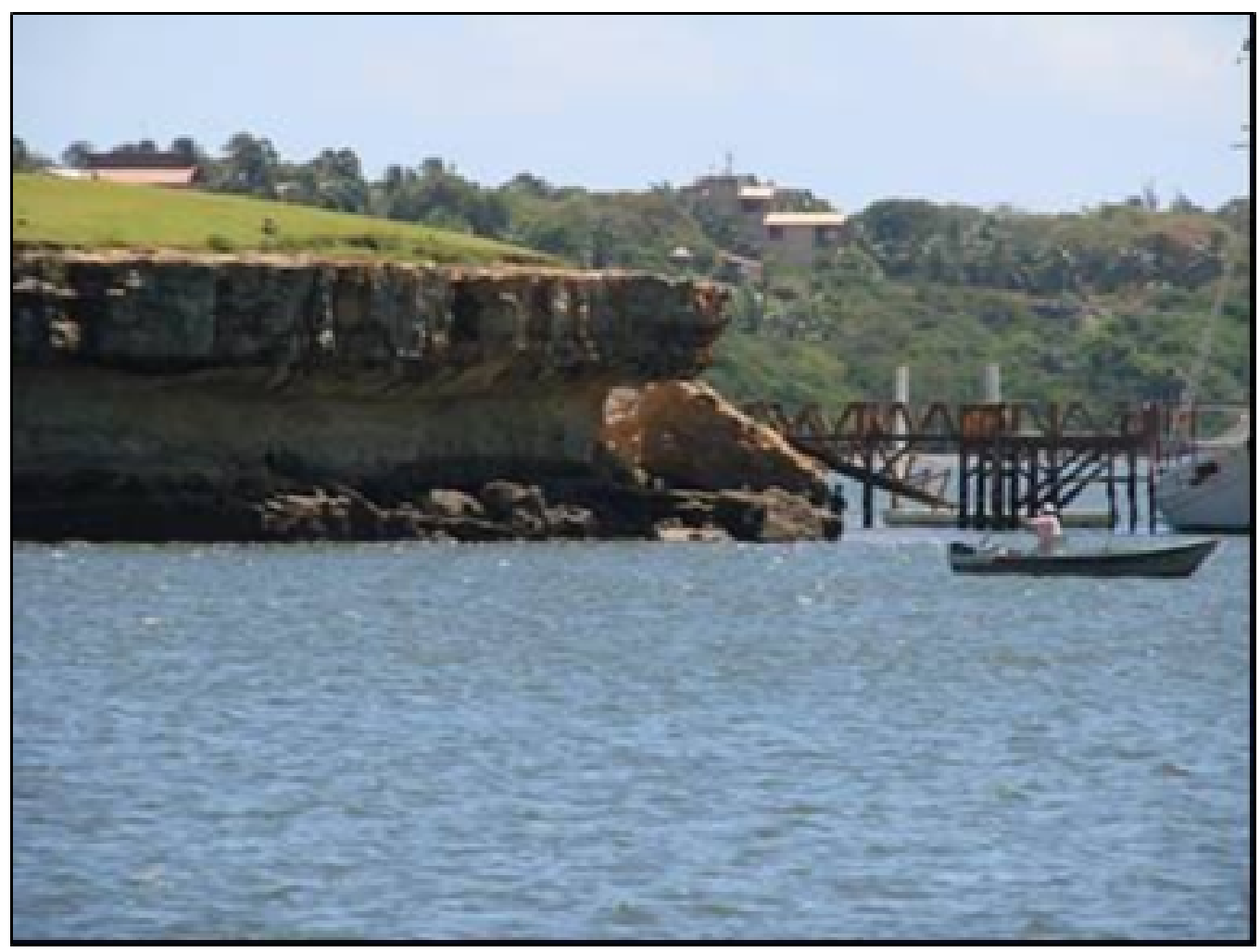

Figura 17: Pedra do Chapéu, falésia produzida na Formação Tibau e trabalhada pelo rio Jaguaribe, em sua margem esquerda, município de Fortim. 
$\mathrm{Na}$ zona litorânea a Formação Barreira é comumente trabalhada na forma de falésias, que são formadas pela ação erosiva das ondas sobre formações geológicas com níveis topográficos mais elevados que as praias atuais, e que recuam formando escarpas. As falésias podem ser consideradas vivas ou mortas, conforme a erosão marinha esteja atuando ou não (CEARÁ, 2006; LABOMAR, 2006). No processo de recuo as falésias deixam à frente plataformas de abrasão que testemunham a posição pretérita do relevo.

$\mathrm{Na}$ área de estudo os sedimentos da Formação Barreiras são tambím trabalhados na forma de falésias inativas ou mortas (Figura 18). Assim como plataformas de abrasão e planícies litorâneas, as falésias resultam diretamente das mudanças do nível do mar.

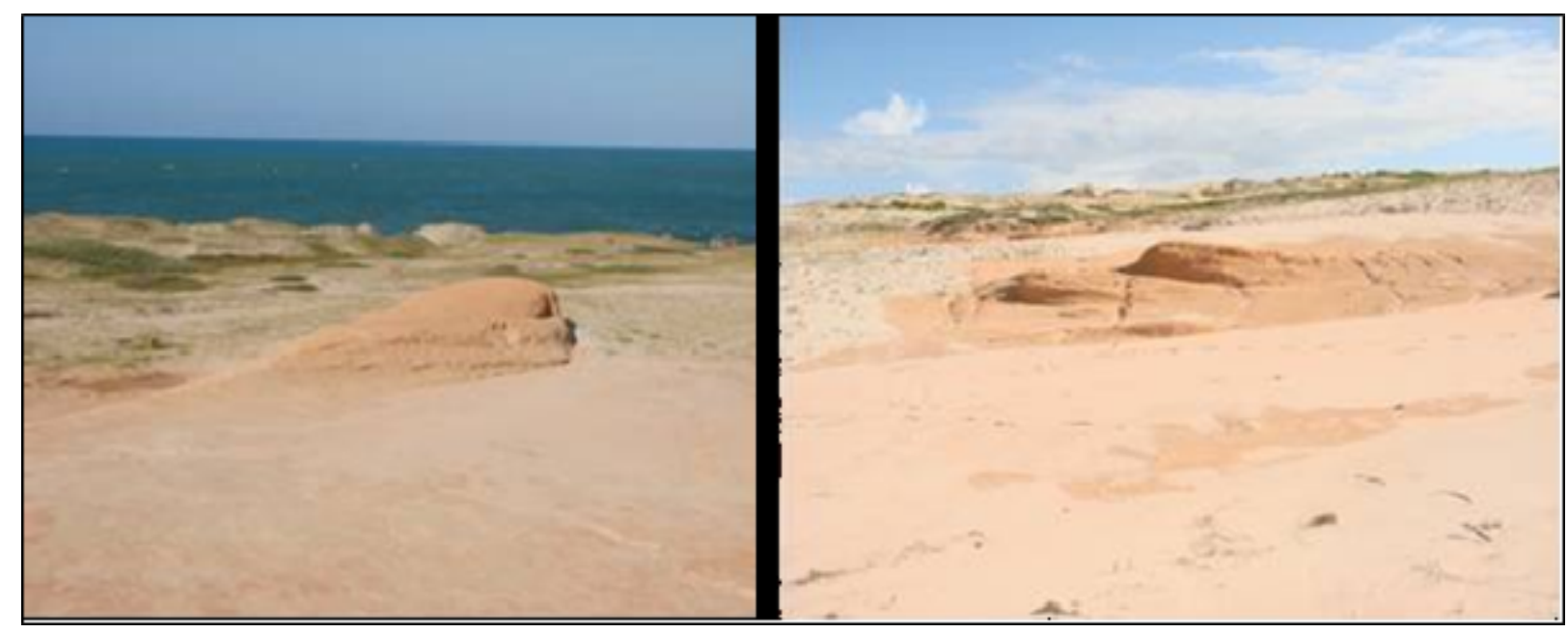

Figura 18: Linha de paleofalésia trabalhada em sedimentos da Formação Barreiras, localidade de Maceió, Fortim - proximidades ma margem esquerda da foz do rio Jaguaribe. À frente da paleofalésia evolui uma planície litorânea moderna.

Se a observação das paleofalésias incidisse apenas no elemento coloração, poderia haver um erro, levando a interpretar essas feições enquanto paleodunas, fato que, com efeito, tem ocorrido sistematicamente na produção científica e técnica local. No entanto, uma análise mais detalhada mostra a presença de grãos de quartzo com granulometria variando de seixos a cascalhos (Figura 19), negando a formação desta feição apenas por trabalho eólico.

\subsection{Problemática Ambiental}

Até meados do século XX os mecanismos naturais atuantes no estuário do Rio Jaguaribe não foram muito alterados em razão de atividades sociais. Mudanças de caráter sócio-ambiental passaram a ocorrer, sobretudo, ao longo das últimas décadas, de forma a modificar o padrão normal de funcionamento natural do sistema, implicando na ocorrência 
de processos de degradação ambiental.

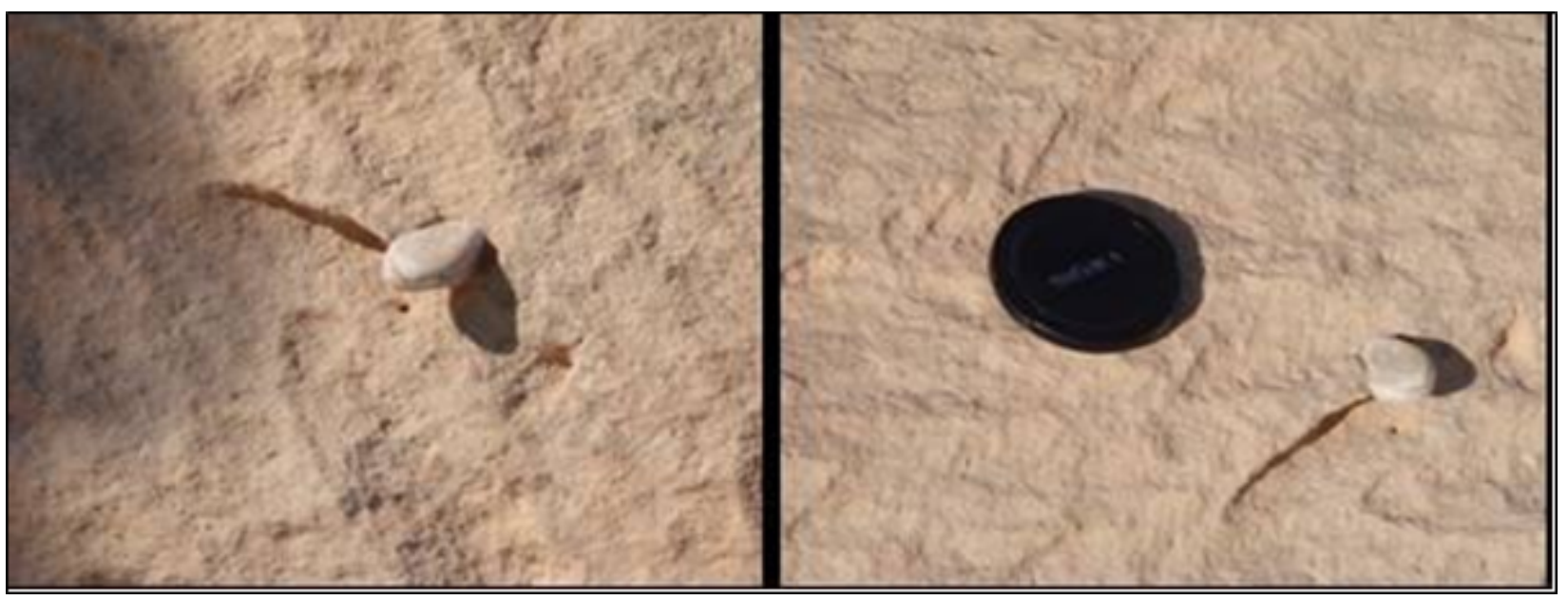

Figura 19: Presença de seixos de quartzo, caracterizando as paleofalésias da localidade de Maceió, Fortim proximidades da margem esquerda da foz do rio Jaguaribe.

O Rio Jaguaribe representa um importante elemento natural da paisagem e do território cearense. As atividades econômicas e sociais que se desenvolvem atualmente no seu médio e baixo curso e no entorno de sua foz são sobretudo a agricultura irrigada, as atividades de carcinicultura, o barramento do curso fluvial para efeito de controle de enchentes e abastecimento de água para fim industrial e urbano, a produção de energia eólica no campo de dunas, além das atividades associadas com o turismo na faixa de praia e no campo de dunas. Essas atividades ampliam a importância da bacia hidrográfica,, transformando esse espaço em lócus de atenção privilegiada por parte dos agentes de produção do espaço geográfico local, nacional e internacional.

Tal atenção fica evidente através do projeto do Governo Federal, em curso, de transposição das águas do Rio São Francisco, a partir do Estado da Bahia, para essa bacia fluvial, na perspectiva, sobretudo, de ampliar as práticas de irrigação voltadas para a produção agrícola destinada a abastecer o mercado internacional de frutas tropicais e fornecer água para atividades industriais, como aquelas associadas ao Porto do Pecém, no litoral central do Ceará.

Um elemento fundamental dessas mudanças ambientais introduzidas nos últimos anos foi a construção da 'mega-barragem' Castanhão, na década de 1990, no médio curso do rio Jaguaribe. O Castanhão teve por objetivo principal, controlar as cheias no baixo curso do Jaguaribe e, nesse sentido, obteve sucesso. Com efeito, os dramas associados às enchentes durante a quadra invernosa desapareceram do cotidiano das populações ribeirinhas que habitam o médio e baixo curso do Jaguaribe, e outras práticas de uso das margens fluviais, 
como associadas à agricultura irrigada, tiveram incentivos, a partir de então.

No entanto, novas situações surgiram como a diminuição do transporte de sedimentos e da carga sólida e de fundo do curso fluvial (LACERDA, 2003; MORAIS e PINHEIRO, 2011), além da eliminação do fluxo de água doce a partir da barragem de Itaiçaba, situado $40 \mathrm{~km}$ à montante da foz. (COGERH, 2018) Tal fato resultou na ampliação de processos de erosão ao longo da zona costeira litorâanea à jusante da foz do rio, conforme constatado em diversos trabalhos (e.g. MORAIS e PINHEIRO, 2011; PEDROSA, 2016).

A carcinicultura também é um sério problema socioambiental no local, pois desmata e polui a planície flúvio-marinha, além de impedir o livro acesso da população de praianos aos recursos naturais que existem na área, antes disponíveis para as atividades de subsistência (GODOY et al., 2018).

Em adição, cita-se que a atividade de instalação e funcionamento de turbinas voltadas para a produção de energia eólica no campo de dunas vem alterando a dinâmica natural da área, implicando em destruição das dunas móveis e diminuição na migração dos sedimentos em direção à planície flúvio-marinha (MEIRELES et al., 2013; PEDROSA, 2016).

Por fim, coloca-se que o turismo, apesar de propiciar ampliação da fonte de renda para setores da população (como bugreiros e comerciantes), também implica em degradação ambiental. O movimento de bugres no campo de dunas vem produzindo compactação das areas interdunares, diminuindo a migração das dunas em direção à margem direita do rio. A diminuição da migração das dunas em direção ao rio mostra-se como mais um elemento responsável pela diminuição do aporte de sedimentos para o rio, e pode implicar em aumento da erosão à jusante da foz do recurso hídrico.

\section{CONCLUSÕES}

Os estudos geoambientais associados com bacias de drenagem assumem grande relevância, tendo em vista que as planícies fluviais, em particular nas zonas costeiras, e sobretudo no semi-árido nordestino, representam um dos espaços mais valorizados, em função de suas potencialidades naturais quanto à ocupação e à exploração dos recursos existentes. Dessa forma, ocorre elevada pressão sobre esses ambientes (e.g. CARVALHONETA, 2007).

Com efeito, o crescimento das populações, quer residentes, quer temporárias, bem como a ampliação de atividades econômicas, vem gerando conflito acrescido entre as 
utilizações concorrentes nas zonas costeiras. As utilizações de impacto reduzido estão sendo frequentemente substituídas por utilizações intensivas, que são lucrativas a curto prazo, mas prejudicam, a longo prazo, as potencialidades do litoral, ao reduzirem a sua resiliência.

O presente trabalho apresentou uma compartimentação geomorfológica da foz do Rio Jaguaribe e áreas costeiras adjacentes, na qual foram consideradas a planície fluvial, a faixa de praia, os campos de dunas móveis e de dunas fixas, a planície flúvio-marinha e os tabuleiros costeiros, além dos condicionantes geoambientais que regulam esse conjunto de elementos. Com isso, ficou evidente que as unidades geoambientais da foz do rio Jaguaribe são o resultado da dinâmica fluvial e da dinâmica litorânea e, mais recentemente, também da dinâmica imposta pela sociedade, que ao longo do tempo molda e transforma tais feições.

Com a apresentação desses elementos naturais e socioambientais, pretendeu-se ampliar e divulgar o conhecimento acerca do ambiente costeiro e flúvio-marinho da area de análise, visando fornecer subsídios para que as utilizações da zona costeira em questão venham a se tornar mais sustentáveis a médio e longo prazo. Essa é uma das formas através das quais a ciência geográfica pode contribuir para o avanço de práticas socioambientais mais responsáveis e equitativas.

\section{REFERÊNCIAS}

BERTRAND, G. Paisagem e Geografia Física Global: Esboço Metodológico. Cadernos de Ciência da Terra. São Paulo, Instituto de Geografia USP, v. 3, p. 1-21, 1969.

CARVALHO-NETA, M. L. Evolução Geomorfológica e Análise Ambiental da Foz do Rio Jaguaribe/Ce. Dissertação de Mestrado, Departamento de Geografia, Universidade Federal do Ceara, 2007.

CARVALHO, A. M.; CLAUDINO-SALES, V.. Instabilidade costeira em um litoral em espiral: o exemplo da praia da lagoinha, Estado do Ceará. Revista Brasileira de Geomorfologia, v. 18, p. 51-64, 2017.

CASTELO BRANCO, M. P. N. Sistemas Deposicionais da Região Costeira do Estado do Ceará (Folhas Parajuru e Aracati). Dissertação de Mestrado. Recife: UFPE, 1996.

CEARÁ. Superintendência Estadual do Meio Ambiente; Instituto de Ciências do Mar et al. Zoneamento Ecológico-Econômico do Ceará - Zona Costeira. Fortaleza: SEMACE, 147 p., 2006.

CHRISTOFOLETTI, A. Análise de sistemas em geografia: introdução. São Paulo: Hucitec: Editora da Universidade de São Paulo, 106 p.,1979. 
CLAUDINO-SALES, V. Cenários Litorâneos. Lagoa do Papicu: natureza e ambiente na cidade de Fortaleza. Dissertação de Mestrado, Universidade de São Paulo, 389 p, 1993.

CLAUDINO SALES, V. Les littoraux du Ceará: evolution geomorphologique de la zone côtiere de I'Etat du Ceará, Brésil - du long terme au court terme. Tese de Doutorado, Universidade Paris Sorbonne, Paris, 511 p., 2002.

CLAUDINO SALES, V. Os litorais cearenses. In: SILVA, J. B. (Org). Ceará, um novo olhar geográfico. Fortaleza: Edições Demócrito Rocha, 231 - 260 p., 2005.

CLAUDINO-SALES, V. Megageomorfologia do Estado do Ceará. São Paulo: NEA Edições, 99 p., 2016.

CLAUDINO-SALES, V.; PEULVAST, J. P. Formas litorâneas: barreiras no litoral do Estado do Ceará. In: Dantas, E.W.C; Meireles, A.J.; Zanella, M.E.. (Org.). Ceará: litoral e sertão, UFC, v. 1, p. 132-141, 2006.

COGERH (COMPANHIA DE GESTÃO DE RECURSOS HIDRÍCOS DO ESTADO DO CEARÁ). Atlas de Recursos Hídricos do Estado do Ceará. http://atlas.cogerh.com.br/. Acessado 21 novembro de 2018.

CPRM (COMPANHIA DE PESQUISA EM RECURSOS MINERAIS). Atlas Digital dos Recursos Naturais do Estado do Ceará. Fortaleza: 2003.

CPRM (COMPANHIA DE PESQUISA EM RECURSOS HINERAIS. Geodiversidade do Estado do Ceara. Fortaleza: 2014.

FIGUEREIDO, A. Vegetação. In: SEMACE. Atlas do Estado do Ceara. Fortaleza, 1997.

FUCKS, S.; CARVALHO, M. S.; CÂMARA, G.; MONTEIRO, A.V.M. (eds). Análise

Espacial de Dados Geográficos. Brasília, EMBRAPA, v. 1. 209 p., 2004.

FUNCEME (FUNDAÇÃO CEARENSE DE METEOREOLOGIA). Plataforma de Coleta de Dados. http://www.funceme.br/app/pcd/mapa/sensor/. Acessado 21 de outubro de 2018.

GATTO, L. C. S. (Ed.). Diagnóstico ambiental da bacia do rio Jaguaribe: diretrizes gerais para a ordenação territorial. Salvador/BA. IBGE, 77p., 1999.

GODOY, M.; MEIRELES, A. J. A.; LACERDA, L. D. Mangrove Response to Land Use Change in Estuaries along the Semiarid Coast of Ceará, Brazil. Journal of Coastal Research, v. 34, p. 524-533, 2018.

GUERRA, A. J. T.; MENDONÇA, J. K. S. Erosão dos solos e a questão ambiental. In: VITTE, A. C.; GUERRA, A. J. T (Org.) Reflexões sobre a geografia física do Brasil. Rio de Janeiro: Bertrand Brasil, 225-256 p., 2004.

HESP, P. A gênese de cristas de praias e dunas frontais. In: MERCATOR - Revista do departamento de Geografia. Fortaleza: UFC, ano 01, n 2, 119-125p., 2002

IPLANCE. Atlas do Ceará. Fortaleza. 64p. (Mapas coloridos - escala 1:1.500.000). 1997. 
LABOMAR. Caracterização sedimentológica da zona estuarina do rio Jaguaribe. UFC/LABOMAR, 18p., 2006.

LACERDA, L. D. Impacto de atividades em bacias de drenagem e mudanças globais sobre a região costeira do semi-árido do nordeste do Brasil. In: CLAUDINO-SALES, V. (Org). Ecossistemas Brasileiros: manejo e conservação. Fortaleza: Expressão Gráfica e Editora, 2003.

LEAL, J. R. L. V. Zoneamento Geoambiental da Área de Proteção Ambiental de Canoa Quebrada - Aracati - Ceará. Dissertação de Mestrado, Universidade Federal do Ceará, Fortaleza, 210p., 2003.

MAIA, L. P. Controle tectônico e evolução geológica sedimentológica da região da desembocadura do rio Jaguaribe - CE. Dissertação de Mestrado, UFPE. Recife, 144 p.. 1993.

MAIA, L. P. Procesos costeros y balance sedimentario a l o largo de Fortaleza (NEBrasil): Implicaciones para una gestión adecuada de la zona litoral. Tesis Doctoral, Universitat de Barcelona, Facultat de Geologia, Departement d'Estratigrafia i Paleontologia, 269p. 1998.

MEIRELES, A. J. A.; GORAYEB, A.; SILVA, D. F. R.; LIMA, G. S. Socio-environmental impacts of wind farms on the traditional communities of the western coast of Ceará, in the Brazilian Northeast. Journal of Coastal Research, v. 65, p. 81-86, 2013.

MENDONÇA, F. A. Diagnóstico e análise ambiental de microbacia hidrográfica. Proposição metodológica na perspectiva do zoneamento, planejamento e gestão ambiental. RA'EGA: O espaço geográfico em análise. Curitiba, PR: Departamento de Geografia/ UFPR, v.3, n3, p.67- 89, 1999.

MENEZES, M. O. B; LEHUGEUR, L. G. O; CASTELO BRANCO, M. P. N. Contribuição geológica à carta de sensibilidade ambiental dos ecossistemas costeiros do litoral leste do Estado do Ceará ao derramamento de óleo. In: CLAUDINO-SLES, V (Org). Ecossistemas Brasileiros: manejo e conservação. Fortaleza: Expressão Gráfica e Editora, 2003.

MELlO, J. A. T. Manguezal ameaçado: impactos sociais e ambientais da criação de camarão em cativeiros. Brasília: Câmara dos Deputados, 42 p., 2005.

MONTEIRO, L. H. U. Estudo das áreas de mangues entre os estados Piauí e Pernambuco com um enfoque para o estado do ceará nos anos de 1978 e 1999/2004 utilizando sensoriamento remoto. Dissertação de Mestrado. Fortaleza: Labomar/UFC,5. 125p, 2005.

MORAIS, J O. Processos de impactos ambientais em zonas costeiras. In: Revista de Geologia. UFC, vol. 9, 191-242p., 1966.

MORAIS, J. O.; PINHEIRO, L. S. The effect of smi-aridity and damming on sedimentary dynamics in estuaries- Northeastern region of Brazil. Journal of Coastal Research, v. 64, p. 1540-1544, 2011. 
MORO, M. F.; MACEDO, M. B.; MOURA-FÉ, M. M.; CASTRO, A. S. F.; COSTA, R. C. Vegetação, unidades fitoecológicas e diversidade paisagística do estado do Ceará. Rodriguésia (Online), v. 66, p. 717-743, 2015.

MUEHE, D. Geomorfologia Costeira. In: GUERRA, A. J. T. e CUNHA, S. B. (org.). Geomorfologia: uma atualização de bases e conceitos. Rio de Janeiro: Bertrand Brasil, 1994.

NASCIMENTO, F. R. Recursos naturais e desenvolvimento sustentável: subsísios ao gerenciamento ambiental na sub-bacia do baixo Pacoti-Ce. Dissestação de Mestrado. Fortaleza: UECE, 154p., 2003.

PEDROSA, A. A. Geodinâmica e morfogênese das dunas eólicas na Praia de Canoa Quebrada, Aracati, Ceará, Brasil. Tese de Doutorado, Departamento de Geologia, Universidade Federal do Ceará, 2016.

PEREIRA, R. C; SILVA, E. V. Solos e Vegetação do Ceará: características gerais. In: SILVA, J. B; CAVALCANTE, T. DANTAS, E. W. C (Org). Ceará, um novo olhar geográfico. Fortaleza: Edições Demócrito Rocha, 2005.

PINHEIRO, L. S.; MORAIS, J. O., MAIA, L. P. The Beaches of Ceará. In: SHORT, A.F., KLEIN, A. H. F. (Orgs.). Brazilian Beaches Systems. Springer International Publishing, v. 1, p. 175-199. 2016.

PINHEIRO, M. V. A; SALES, M. C. L. Determinação do balanço hídrico como subsídio para o estudo da dinâmica costeira cearense. In: Anais do XII Simpósio Brasileiro de Geografia Física Aplicada. Natal, UFRN, 8 a 13 de julho de 2007.

POR, F. D. Guia ilustrado do manguezal brasileiro. São Paulo: Instituto de Biociências da USP,. 82p. , 1994.

RODRIGUEZ, J. M; SILVA, E. V; CAVALCANTE.A. P. B. Geoecologia das paisagens: uma visão geossistêmica da análise ambiental. EDUFC, Fortaleza,. 222 p., 2004.

SEMACE. Superintendência do Meio Ambiente do Estado do Ceará. Disponível no endereço: www.semace.ce.gov.br acesso em abril 2018.

SILVA, E. V. Geoecologia da paisagem do litoral cearense: uma abordagem a nível de escola regional e tipologia. Tese de Professor Titular, Departamento de Geografia, UFC, Fortaleza, 282 p., 1998.

SNUC. Sistema Nacional de Unidades de conservação: texto da Lei 9.985 de 18 de julho de 2000 e vetos da presidência da República ao PL aprovado pelo congresso Nacional. São Paulo: Conselho Nacional da Reserva da Biosfera da Mata Atlântica, 76 p., 2000.

SOTCHAVA, V. B. O Estudo dos Geossistemas. Método em Questão. n 16, IGEO/ USP. São Paulo, 1977.

SOUZA, M. J. N. Contribuições ao estudo das unidades morfoestruturais do Ceará. In: Revista de Geologia, vol. 1. 1988. 
SOUZA, M. J. N. Bases naturais e esboço do zoneamento geoambiental do estado do Ceará. In: Lima, L. C. Compartimentação Territorial e Gestão Regional do Ceará. Fortaleza: FUNECE,; 6-98p., 2000.

SOUZA, M. J. N; VIDAL, W. P. O; GRANGEIRO, C. M. M. Análise Geoambiental. In: ELIAS, D. (Org). O novo espaço da produção globalizada: o baixo Jaguaribe/CE. Fortaleza: FUNECE,. 23 - 89 p., 2002.

TRICART, J. Ecodinâmica. Rio de janeiro. IBGE, 97 p. 1977.

TROPPMAIR, H. Sistemas, geossistemas, geossistemas paulistas, ecologia da paisagem. Rio Claro: São Paulo, 1989.

VIDAL, M. R. Proposta de gestão ambiental para a Reserva Extrativista do Batoque Aquiraz/Ce. Dissertação de Mestrado. UFC, Fortaleza:. 156 p. 2006.

ZANELLA, M. E. As características climáticas e os recursos hídricos do Ceará. In: SILVA, J. B; CAVALCANTE, T. DANTAS, E. W. C (Org). Ceará, um novo olhar geográfico, Edições UFC, $2^{a}$ edição, Fortaleza, 2007.

Recebido em: 22/01/2019

Aceito para publicação em: 11/06/2019 